
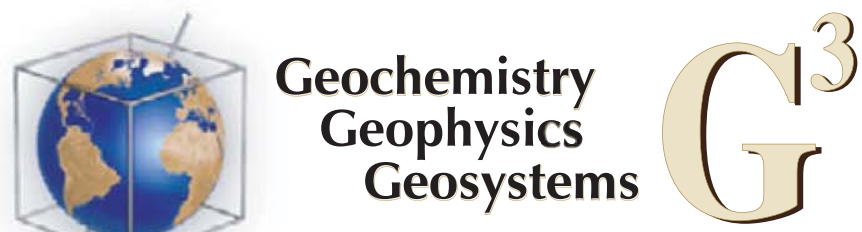

\title{
Strong sediments at the deformation front, and weak sediments at the rear of the Nankai accretionary prism, revealed by triaxial deformation experiments
}

\author{
Michael Stipp \\ Department of Marine Geodynamics, GEOMAR Helmholtz Centre for Ocean Research Kiel, Kiel, Germany \\ (mstipp@geomar.de) \\ Malte Rolfs \\ Institute of Geotechnical Engineering and Construction Management, TU Hamburg-Harburg, Hamburg, Germany
}

\section{Yujin Kitamura}

Department of Earth and Planetary Science, University of Tokyo, Tokyo, Japan

\author{
Jan H. Behrmann and Kai Schumann \\ Department of Marine Geodynamics, GEOMAR Helmholtz Centre for Ocean Research Kiel, Kiel, Germany
}

\section{Detlef Schulte-Kortnack and Volker Feeser \\ Department of Engineering Geology, Institute of Geosciences, University of Kiel, Kiel, Germany}

[1] Nineteen whole-round core samples from the Nankai accretionary prism (IODP Expeditions 315, 316, and 333) from a depth range of 28-128 m below sea floor were experimentally deformed in a triaxial cell under consolidated and undrained conditions at confining pressures of 400-1000 kPa, room temperature, axial displacement rates of $0.01-9.0 \mathrm{~mm} / \mathrm{min}$, and up to axially compressive strains of $\sim 64 \%$. Despite great similarities in composition and grain size distribution of the silty clay samples, two distinct "rheological groups" are distinguished: The first group shows deviatoric peak stress after only a few percent of compressional strain $(<10 \%)$ and a continuous stress decrease after peak conditions. Simultaneous to this decrease is a pore pressure increase indicating contractant behavior characteristic of structurally weak material. The second sample group weakens only moderately at a much higher strength level after significantly higher strain $(>10 \%)$, or does not weaken at all. This is characteristic of structurally strong material. The strong samples tend to be overconsolidated and are all from the drillsites at the accretionary prism toe, while the weak and normally consolidated samples come from the immediate hanging wall of a megasplay fault further upslope. Sediments from the incoming plate are also structurally weak. The observed differences in mechanical behavior may hold a key for understanding strain localization and brittle faulting within the uniform silty and clayey sedimentary sequence of the Nankai accretionary prism.

Components : 13,505 words, 12 figures, 2 tables.

Keywords : clay-rich soft sediments; failure; distributed ductile and localized brittle deformation; surface break; updip end of the seismogenic zone; NanTroSEIZE.

Index Terms: 8170 Subduction zone processes: Tectonophysics; 8118 Dynamics and mechanics of faulting: Tectonophysics; 8164 Stresses: crust and lithosphere: Tectonophysics; 1031 Subduction zone processes: Geochemistry; 3613 Subduction zone processes: Mineralogy and Petrology; 8413 Subduction zone processes: Volcanology; 5104 Fracture and flow: Physical Properties of Rocks; 3036 Ocean drilling: Marine Geology and Geophysics; 3060 Subduction zone processes: Marine Geology and Geophysics; 8004 Dynamics and mechanics of faulting: Structural Geology.

Received 9 August 2013; Revised 9 October 2013; Accepted 9 October 2013; Published 8 November 2013. 
Stipp, M., M. Rolfs, Y. Kitamura, J. H. Behrmann, K. Schumann, D. Schulte-Kortnack, and V. Feeser (2013), Strong sediments at the deformation front, and weak sediments at the rear of the Nankai accretionary prism, revealed by triaxial deformation experiments, Geochem. Geophys. Geosyst., 14, 4791-4810, doi:10.1002/ggge.20290.

\section{Introduction}

[2] Faulting (or fault slip) as well as earthquake nucleation and propagation are commonly assumed to be controlled by friction and stick-slip instabilities [e.g., Brace and Byerlee, 1966; Scholz, 1998]. Many theoretical conceptions of friction on fault surfaces, especially the rate and state-variable friction law, have been developed [e.g., Dieterich, 1972, 1979; Rice and Ruina, 1983; Chester, 1994; Scholz, 2002]. They have been constrained and recessed by a wealth of experimental data [Tullis and Weeks, 1986; Blanpied et al., 1991; Linker and Dieterich, 1992; Beeler et al., 1994; Goldsby and Tullis, 2002]. All these findings well explain the mechanics and deformation processes within the upper seismogenic zone and toward its downdip termination. Deformation at the updip end of the seismogenic zone and the lack of earthquakes in the uppermost section of the crust in subduction zones is less well understood. It is also a matter of debate why faults do or do not cut through this crustal section when a major earthquakes occurs in the seismogenic zone and propagates in updip direction.

[3] The updip end of the seismogenic zone usually occurs in a depth range of 5-10 km at temperatures between 100 and $150^{\circ} \mathrm{C}$ where pore space reduction, dewatering, and consolidation are already advanced [e.g., Cloos, 1982; von Huene, 1984; Byrne et al., 1988; Vrolijk, 1990; Hyndman and Wang, 1993; Moore and Saffer, 2001]; for the Nankai accretionary prism the depth is approximately $5 \mathrm{~km}$ [Moore et al., 2001; Park et al., 2002a, 2002b; Kimura et al., 2007]. The transition from aseismic to seismic deformation toward depth is ascribed to a number of different processes including changes in the frictional behavior of clay minerals, hardening of the aseismic subduction thrust, the diagenesis of the involved sedimentary rocks, pore pressure reduction, and stepdown of the subduction thrust due to underplating [e.g., Marone and Scholz, 1988; Hyndman and Wang, 1993; Hyndman et al., 1997; Oleskevich et al., 1999; Moore and Saffer, 2001; Saffer and Marone, 2003; Kitamura et al., 2005; Kimura et al., 2007]. The contributions of these processes have been estimated by theoretical considerations on the critical wedge taper, experimental data, and modelling. Most of these processes are controlled by temperature, but also rock compostion, fluid pressure and regional stress field could be important [Hyndman and Wang, 1993; Tichelaar and Ruff, 1993; Oleskevich et al., 1999; Wallace et al., 2009].

[4] For surface breaks and thus for the faulting of the crustal section above the seismogenic zone the mechanical as well as compositional and microstructural properties of the rocks are most important and temperature is only of minor importance. While the depth range of lithification is assumed to correspond to beginning seismicity increasing from there downward, the rheological contrast between hard and soft rocks (sediments) upward is crucial for the upward propagation of faults. Careful compositional and microstructural analyses as well as geotechnical experiments are essential to characterize this transition and the capacity of the overlying sediments to establish and maintain discrete faults and produce surface breaks.

[5] Sediments in accretionary prisms usually undergo considerable bulk strain, they tend to be underconsolidated with a low degree of lithification due to fast burial and high internal fluid pressure [for recent reviews see Underwood, 2007; Morgan et al., 2007]. The accretionary prism sediments predominantly consist of mixtures of quartz, feldspar, carbonates, and sheet silicates with different grain size distributions. The sheet silicates play a key role for rock friction and mechanically weak behavior [e.g., Byerlee, 1978; Vrolijk, 1990; Beeler, 2007]. Mixtures of quartz and smectite, for example, weaken considerably when smectite contents in the fault zone exceed about 30\% [Lupini et al., 1981; Logan and Rauenzahn, 1987].

[6] For the clay-dominated soft sediments prevailing in accretionary prisms above the seismogenic zone, the brittle to plastic behavior, brittle or plastic peak stress and residual stress, pore pressure characteristics and the processes governing strain localization are important for faulting. The most promising approach to study these processes may be by consolidated and undrained triaxial testing [e.g., Laberg et al., 2003; Sultan et al., 2004; Morgan et al., 2007; Kitajima et al., 2012]. While 
reaching peak deviatoric stress in constant displacement rate tests, the compressibility of the sediment increases together with an increase in pore pressure [Terzaghi et al., 1996]. A significant decrease in deviatoric stress after reaching peak stress (failure point) combined with an increase in pore pressure under undrained conditions is characteristic of structurally weak material [e.g., Sultan et al., 2004]. Such material shows contractant behavior, develops shear bands, and may be inherently unstable under application of a critical load. In contrast, for structurally strong material the residual stress remains constant at peak stress level or there is even a continuous stress increase together with a decrease in pore pressure toward high strain $(>20 \%)$. This material behavior is dilatant and deformation without the development of shear bands is believed to be stable under the same loading conditions as applied to the structurally weak material [Laberg et al., 2003].

[7] The Nankai Trough Seismogenic Zone Experiment (NanTroSEIZE) drilling project of the Integrated Ocean Drilling Program (IODP) in the SW Japan forearc is the first-ever attempt to core and instrument the updip end of the seismogenic part of a subduction zone [review in Dixon and Moore, 2007; Tobin and Kinoshita, 2007; Moore et al., 2009]. Hence, the project is dedicated to plate boundary deformation, accretionary prism formation and the upper seismogenic zone of the Nankai trench at which the Philippine Sea plate is subducted below the Japanese islands Honshu and Shikoku (Eurasian plate). IODP Expeditions 315, 316, and 333 from which our experimental samples are recovered, investigated the shallow frontal thrusts, the hanging wall to a major active splay fault of the active frontal thrust system and the incoming plate material [e.g., Kinoshita et al., 2009; Tobin et al., 2009; Henry et al., 2011]. The sample material is well suited to test whether the involved sediments are dominated by localized brittle deformation and subsequent fault slip, or alternatively, by distributed ductile deformation causing a slow, creep-like behavior on the megascopic scale. Knowing the mechanical behavior of the sediments within the accretionary wedge is equally important to the study of the decollement, as most of the interplate displacement must be accommodated there, and the response to loading (ductile flow, fracturing, slow aseismic, or fast unstable slip) is crucial to the questions whether earthquake faulting can break toward the surface or not. Slow strain dissipation over days, weeks, or months tends to prevent surface breaks, and associated devastating tsunamis. The undrained triaxial experiments reported here will, therefore, provide a first-order indication as to whether tectonic mass movement in the frontal and middle part of the Nankai forearc constitutes a major tsunami risk.

\section{Geological Setting}

[8] The Nankai Trough is a convergent plate boundary where the Philippine Sea plate subducts beneath the Eurasian plate at rates of 4.0-6.0 cm/y (Figure 1) [Seno et al., 1993; Miyazaki and Heki, 2001]. The subducting Shikoku Basin off southwestern Japan was formed by backarc spreading during a time period of approximately $15-25 \mathrm{Ma}$ [e.g., Okino et al., 1994; Ike et al., 2008]. The convergence direction is approximately normal to the trench, and sediments of the Shikoku Basin are actively accreting at the deformation front [e.g., Kimura et al., 2007].

[9] NanTroSEIZE is a multiexpedition project in the framework of IODP, which consists of four research stages. By the end of the second stage, five expeditions conducted drilling at 12 sites (IODP Sites C0001 to C0012) along a transect almost perpendicular to the Nankai Trough offshore of Kii Peninsula, central Japan. Investigated samples in this paper are obtained from Site C0001 of Expedition 315 [Ashi et al., 2008], Sites C0004, C0006, C0007, and C0008 of Expedition 316 [Kimura et al., 2008] as well as Sites C0011 and C0012 of Expedition 333 [Henry et al., 2011] (Table 1). The 315 and 316 samples were recovered near one of the two major fault systems of the megasplay fault and the frontal thrust (Figure 2) [Park et al., 2002a; Tobin and Kinoshita, 2006]. Sites $\mathrm{C} 0001$ and $\mathrm{C} 0004$ are located along the slope of the accretionary prism landward of the inferred intersection of the megasplay fault zone with the seafloor, and C0008 is in the slope basin seaward of the megasplay fault, while Sites C0006 and $\mathrm{C} 0007$ are from the frontal thrust region in the accretionary prism toe. Sites C0011 and C0012 represent sediments from the incoming plate Henry et al., 2011].

[10] Site C0001 was cored to $458 \mathrm{~m}$ core depth below seafloor (mbsf) covering a "slope basin" (Unit I: 0-207.17 mbsf; facies names with double quotations are from Kinoshita et al. [2009]) within the slope apron facies and the underlying "accretionary prism" (Unit II: 207.17-456.50 mbsf). The slope basin is composed mainly of Quaternary to 


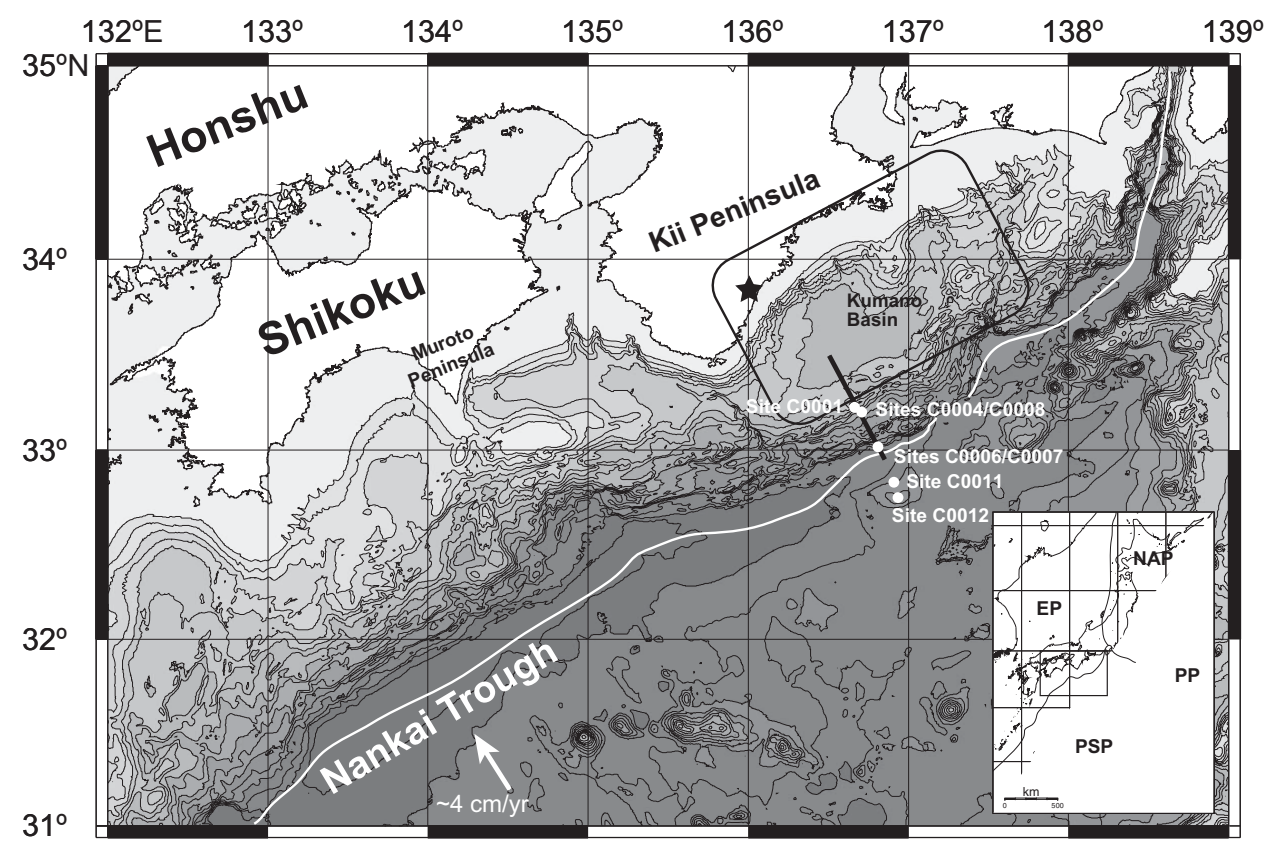

Figure 1. Map of Nankai Trough area, showing the locations of NanTroSEIZE drilling sites C0001, C0004, C0006, C0007, C0008, C0011, C0012 with white dots (IODP Legs 315, 316, and 333; modified after Kitamura et al. [2010]). Seismic reflection profile of Figure 2 was obtained along the black line (seismic transect KR0108-5). Rectangular frame and star corresponds to the rupture zone and the epicenter of the 1944 Tonankai earthquake. EP, Eurasian plate; NAP, North American plate; PP, Pacific plate; PSP, Philippine Sea plate.

late Pliocene silty clay and clayey silt with intercalations of volcanic ash. Unit II is composed of mud-dominated sediments of late Pliocene to late Miocene age. Our sample at this site is from Unit I.

[11] Site C0004 penetrates the megasplay fault zone, and four lithologic units were defined. The uppermost "slope-apron facies" (Unit I: 0-78.06 mbsf) is dominated by greenish gray silty clay

Table 1. List of Drill Core Samples From Nankai Trough Area With Depth Indication, Porosity, Pore Water Data and Related Experiment Numbers. ${ }^{\text {a }}$

\begin{tabular}{lrlcc}
\hline Core Number & $\begin{array}{r}\text { Depth } \\
\text { (mbsf) }\end{array}$ & Experiments & $\begin{array}{r}\text { Porosity } \\
\text { (vol. \%) }\end{array}$ & $\begin{array}{c}\text { Pore } \\
\text { Water } \\
\text { (wt. \%) }\end{array}$ \\
\hline 315-C0001E-11H-1 & 90.62 & K003/K005 & 61.7 & 64.8 \\
316-C0004C-8H-2 & 65.26 & K004/K010 & 63.8 & 62.1 \\
316-C0006E-8H-1 & 48.23 & K007/K009 & 48.9 & 37.2 \\
316-C0006E-20X-2 & 127.98 & K013/K019 & 47.7 & 34.8 \\
316-C0007C-7X-1 & 62.89 & K011/K012/ & 51.6 & 48.3 \\
& & K016 & & \\
316-C0008A-9H-3 & 76.06 & K002/K006/ & 52.2 & 40.0 \\
& & K014 & & \\
316-C0008C-7H-8 & 60.96 & K015/K018 & 56.8 & 50.5 \\
333-C0011D-2H-2 & 33.10 & K020 & 64.0 & 41.0 \\
333-C0012C-4H-5 & 28.90 & K022 & 72.0 & 49.0 \\
\hline
\end{tabular}

${ }^{\text {a}}$ Porosity and pore water data are taken from IODP shipboard measurements carried out on core segments next to our core samples [Ashi et al., 2008; Kimura et al., 2008; Henry et al., 2012]. with a substantial component of calcareous nannofossils and a lesser amount of siliceous biogenic debris, which have been deposited from early to late Pleistocene. Our sample at this site is from Unit I. Below an angular unconformity, separating Units I and II, the "upper accretionary prism" (Unit II: 78.06-258.01 mbsf) is characterized by silty clay of late to middle Pliocene. A mass transport complex was observed in the upper part of Unit II. Unit III (258.01-307.52 mbsf) is a middle Pliocene "structurally bounded package" with two age reversals at both the upper and lower boundary. Unit IV (307.52-398.79 mbsf) is an "underthrust slope facies" of the early Pleistocene and consists of silty clay with a moderate amount of calcareous nannofossils and a lesser amount of calcareous and siliceous microfossils.

[12] Site C0008 is a slope basin located $\sim 1 \mathrm{~km}$ seaward of Site C0004. Two lithologic units were recognized. The "slope sediments" of Unit I (0272.46 mbsf at Hole C0008A, 0-176.20 mbsf at Hole C0008C) are divided into two Subunits IA and IB. Subunit IA from which our samples at this site come from is characterized by greenish gray silty clay with a substantial component of calcareous nannofossils, siliceous biogenic debris, and volcanic ash. Volcanic ash layers are distributed 


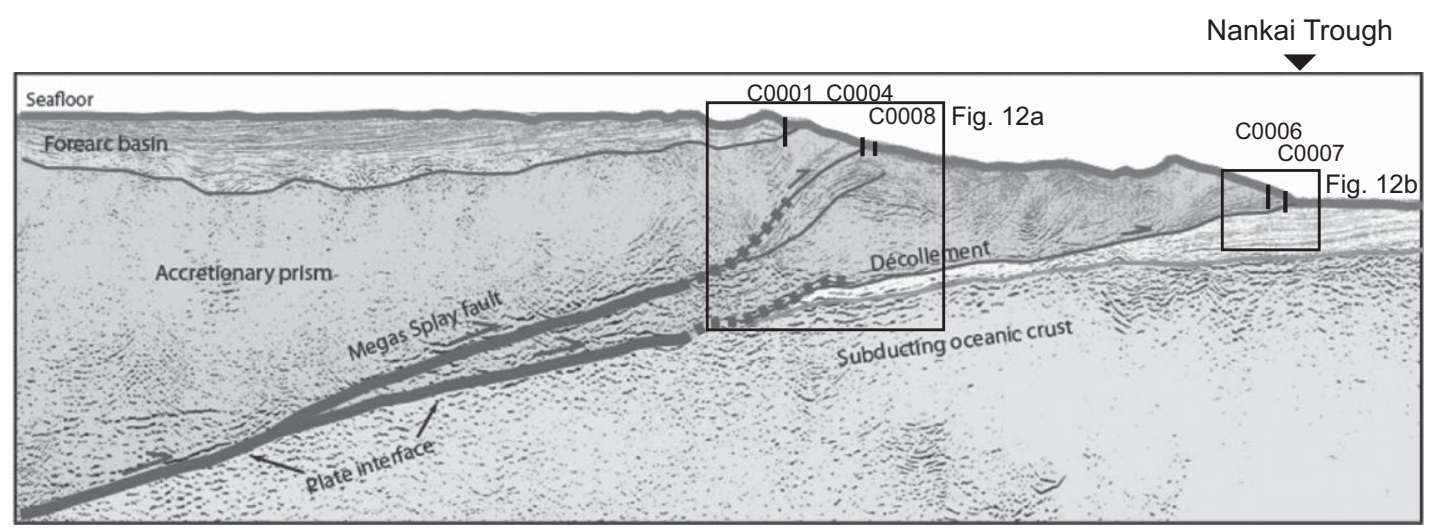

Figure 2. Seismic cross section of the plate boundary from Park et al. [2002a] with geological interpretation of Kimura et al. [2008] along the transect KR0108-5 (black line in Figure 1). NanTroSEIZE drilling sites cored during IODP Expeditions 315 and 316 are shown. The two rectangular frames indicate locations of detailed seismic sections of Figures 12a and 12b.

throughout this subunit. Subunit IB consists of a series of interbedded mudclast gravels and silty clay beds, which are interpreted as a masstransport complex. Underlying Unit II (272.46329.36 mbsf at Hole C0008A) are "sand-rich turbidites" that consist of dark gray fine to coarsegrained and locally pebbly sandstone with minor silty clay interbeds.

[13] Sites C0006 and C0007 targeted the main frontal thrust at the seaward edge of the accretionary prism. Unit I ("trench to slope transition facies") of Site C0006 consists of a fining-upward succession of silty clay, sand, silty sand, and rare volcanic ash layers of Pleistocene-Holocene age. Unit II are accreted "trench deposits" with coarsening upward trend which are divided into four Subunits IIA to IID based mainly on variations in silt and sand content. One of our samples was taken from the "sand-dominated trench wedge" of Subunit IIA, another one from the "mixed sandmud trench wedge" of Subunit IIB, however, we chose the silty part. Underlying Unit III representing a "deep-marine basin" consists of greenish gray to grayish silty clay with some interbedded volcanic tuff layers, including dolomite-cemented and calcite-cemented ash. Site C0007 is located trenchward of Site C0006 and was drilled after the hole condition at Site C0006 precluded to reach the frontal thrust. The lithology of Site C0007 resembles that one of Site C0006 and has Unit IV of possible Pleistocene age sediments beneath the frontal thrust. Our sample at Site C0007 is from Unit IIA of the accreted trench deposits.

[14] Sites C0011 and C0012 were drilled into the sedimentary sequence of the incoming Philippine Sea plate. The topmost Unit I ranges down to
347.82 mbsf at Site C0011 and 149.77 mbsf at Site C0012. The significant difference in layer thickness between the two adjacent drill sites is due to the fact that Site C0012 is located on top of a bathymetric and basement high whereas Site C0011 was cored on the lower northwest flank of this high. Both investigated samples from the two sites belong to Subunit IA consisting of greenish gray clay to silty clay with intercalations of clayey silt, grayish silty clay and $<50 \mathrm{~cm}$ thick volcanic ash layers. The clayey and silty sequence is composed of clay minerals, quartz, feldspar, calcareous nannofossils, and some diatoms [Henry et al., 2011] characteristic of deep-sea clay with some planktonic fossils. These "undisturbed" sediments are used as experimental reference material in comparison to the Nankai accretionary prism samples which are partly deformed and variably consolidated.

\section{Methods}

[15] Grain size and composition analysis, experimental sample preparation as well as setup, resaturation, and pressurization of the geotechnical tests are given in supporting information. ${ }^{1}$ Here we will describe the different types of triaxial deformation experiments on the $50 \mathrm{~mm}$ diameter cylindrical samples (Figure $3 \mathrm{a}$ ) with a length to diameter ratio between $1: 1$ and 2:1 [cf. Vardoulakis, 1979] in axial compression (i.e., $\sigma 1>\sigma 2=\sigma 3$ ). The deformation experiments have been carried out in a triaxial cell according to the standards of Berre [1985] under consolidated and undrained

\footnotetext{
${ }^{1}$ Additional supporting information may be found in the online version of this article.
} 

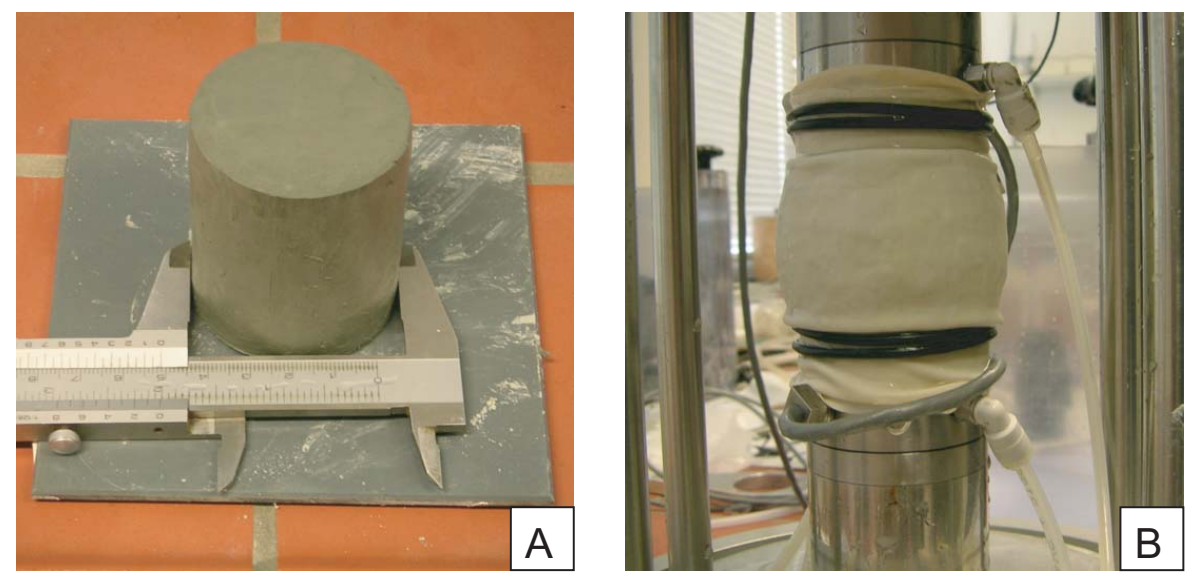

Figure 3. (a) Undeformed sample after resizing of the drill core to a $50 \mathrm{~mm}$ diameter cylinder. Whitish coloring on the sample sides indicate some drying effects at the end of the preparation procedure. (b) Deformed sample after $\sim 40 \%$ axial strain. The sample is still inside the rubber sleeve and between upper and lower forcing pistons. Two O-rings (black) at each piston end prevent infiltration of confining water into the sample. The sample cell is demounted and the confining pressure cylinder is removed.

conditions (CU test) at confining pressures of 400$1000 \mathrm{kPa}$, room temperature, axial displacement rates of $0.01-9.0 \mathrm{~mm} / \mathrm{min}$, and up to axial compressive strains of $\sim 64 \%$ (Figure $3 \mathrm{~b}$ ). Only core samples from low depth $(<128 \mathrm{~m})$ have been selected (Table 1) so that the maximum confining pressure of the triaxial cell comes close or above the in situ overburden stress.

[17] Three different geotechnical deformation tests were performed: (1) single step compression experiments at constant confining pressure and displacement rate, (2) pressure stepping compression experiments at constant displacement rate and three different confining pressures [cf. Head, 1998], and (3) displacement rate stepping compression experiments at constant confining pressure and increasing displacement rate. Single step compression experiments show the general stress/ strain record of a sample including elastic and plastic loading, peak or fracture strength, stress drop, and residual strength in the brittle, and creep strength, weakening or hardening in the plastic deformation case. They were also carried out to record the pore pressure development, and to distinguish between structurally weak and strong behavior [e.g., Sultan et al., 2004]. Pressure stepping experiments allow to determine peak strength at three different confining pressures in one and the same experiment. From that Mohr diagrams can be plotted and effective shear parameters (internal friction angle and cohesion) determined. The third group of experiments investigates displacement rate and pore fluid disequilibrium effects on sample strength. Both, pressure and displacement rate stepping experiments allow to investigate the same parameters as the single step compression experiments with the restriction of lower strain values in the individual steps.

[18] Pressure and displacement rate steps were run until peak stress (stopped just before failure), i.e., when the slope of the stress-strain diagram is zero. In some experiments, however, there was a continuous strength increase without failure. These experiments were stopped after a certain amount of strain to allow additional steps at higher confining pressure or higher displacement rate. Only the ultimate pressure or displacement rate step in the experiments was run past peak stress in order to investigate weakening, high strain deformation behavior and residual strength. At the end of each pressure or displacement rate step the $\sigma 1$-piston was retracted at rates of -0.01 to $-0.1 \mathrm{~mm} / \mathrm{min}$ until isotropic stress conditions were achieved. For the pressure stepping experiments, the confining pressure was then increased under drained conditions. The pore pressure release lasted longer and was awaited until the pore pressure reached the back pressure level within a few kilopascals (usually overnight, 14-20 h) prior to starting the next deformation step (CU test). We will focus on the deformation part(s) of each experiment under undrained conditions neglecting the experimental phases of saturation, pressurization/(re-)consolidation, pore pressure equilibration, and piston retraction/force release carried out at drained conditions (see supporting information). 


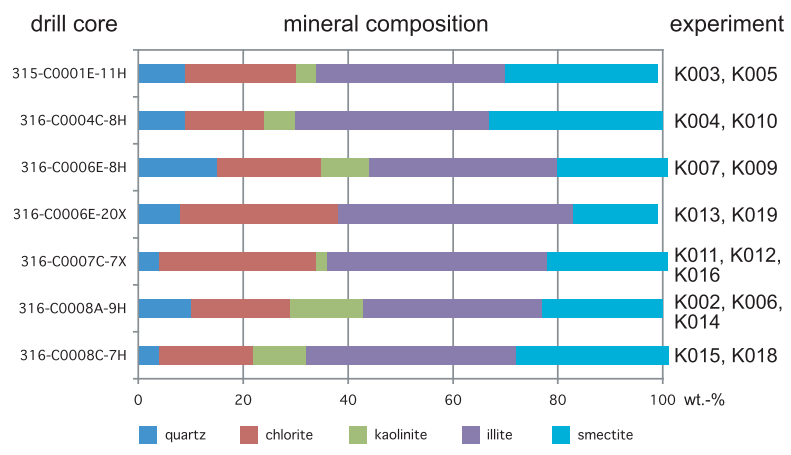

Figure 4. Mineral composition of the grain size fraction $<2$ $\mathrm{mm}$ from XRD-analysis data of Guo and Underwood [2012] in weight percentage. XRD measurements were carried out on the same core segment within $0.50 \mathrm{~m}$ from the experimental starting material. Correlated experimental sample numbers are indicated, but sample to sample variations are possible and not considered.

\section{Experimental Starting Material}

\subsection{Composition}

[19] The mineral composition of the core samples from the accretionary prism is indicated (Figure 4) based on XRD analysis of the grain size fraction $<2 \mu \mathrm{m}$ [Guo and Underwood, 2012]. Thus, a variation for the entire samples due to the existing larger grain size fractions, mainly the silt fraction, is possible, but full compositional data for that are not available. The content of illite amounts to 34$45 \%$ (wt. $\%$ in the following), smectite to $16-$ $33 \%$, chlorite to $15-30 \%$, quartz to $4-15 \%$, and kaolinite to $0-14 \%$ for all the investigated samples from the accretionary prism. Cores from the prism toe (C0006 and $\mathrm{C} 0007)$ have the lowest contents in smectite (16-23\%), those from the slope apron facies in the hanging wall of the megasplay fault have the highest contents $(29-33 \%$; C0001 and C0004) and the slope sediments from the footwall of the megasplay fault are intermediate (23-29\%; C0008). The other minerals are less clear in their distribution (Figure 4). The prism toe deposits (C0006 and C0007) are relatively rich in illite (36-45\%) and chlorite (20-30\%) and poor in kaolinite $(0-9 \%)$, but the variability is large. The slope apron facies (C0001 and C0004) is poor in kaolinite $(4-6 \%)$ as well as in chlorite $(15-21 \%)$ and mediocre in illite (36-37\%). Slope sediments from below the megasplay fault have the highest kaolinite content and intermediate to low contents in chlorite (18-19\%) and illite (34-40\%). The quartz distribution seems to be arbitrary; prism toe and slope sediments vary from 4 to $15 \%$ and from
4 to $10 \%$, respectively, while sediments of the slope apron facies are intermediate and constant at $9 \%$. Overall the sample material is quite homogeneous, but slight, distinct differences especially in the smectite content are existing.

[20] The point counting-analysis of the smear slides allows to semiquantitatively determine the content of biogenic and volcanoclastic material (mainly fossils and ash) versus the content of minerals and lithics and the content, which is too small for light-optical microscopy distinction (submicroscopic material; Figure 5). Hence, by this method also the larger than clay-size fraction is analyzed. Fossils are mainly foraminifera, diatoms, silicoflagellates, sponge needles, and radiolaria. Minerals consist of quartz, feldspar, pyroxene, hornblende, mica, olivine, augite, amphibole, calcite, and opaque minerals (pyrite, etc.). The submicroscopic content varies significantly from 33 to $78 \%$ (point counting $\%$ in the following) across the entire sample set. The prism toe deposits (C0006 and C0007) have a relatively high content in submicroscopic particles (43-78\%), while the slope apron facies (C0001 and C0004) and the slope sediments (C0008) have a lower content $(37-51 \%$ and $33-$ $56 \%$, respectively; Figure 5). Sites $\mathrm{C} 0001$ and C0004 are poor in minerals $(7-10 \%)$ and lithics $(4-11 \%)$, site C0008 is rich in minerals (13-16\%)

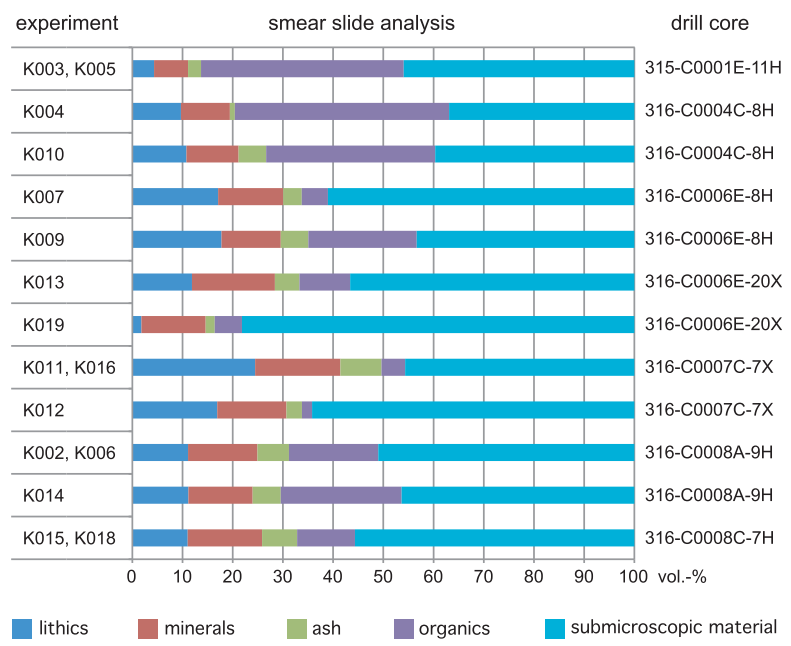

Figure 5. Results of the smear slide analysis from the experimental samples in volume percentage. The drill core number is also indicated. From some of the drill cores (e.g., 316C0004C-8H) independent analyses of the different experimental samples (K004 and K010 for that core) have been carried out allowing to estimate internal drill core variations and measurement error. From other cores (e.g., 315-C0001E-11H; K003 and K005) only a sample average has been determined and variations are therefore unknown. 


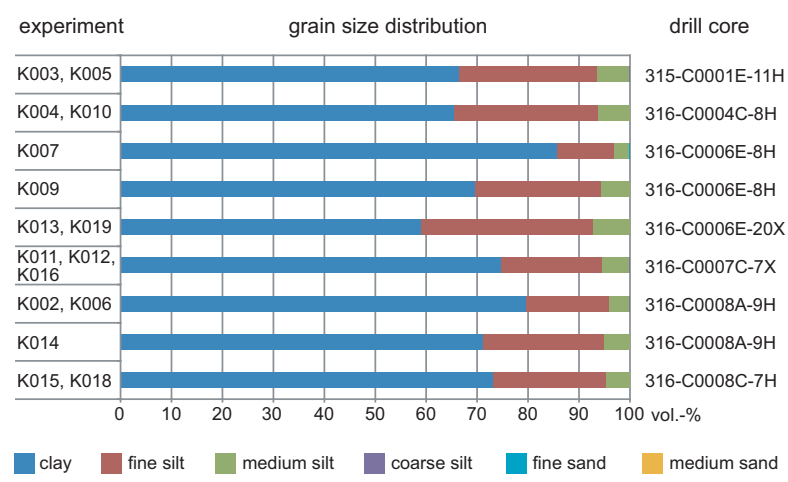

Figure 6. Grain size distribution of drill cores/experimental samples as determined by laser particle sizer analysis in volume percentage. Variations in grain size distribution are generally small. From two of the drill cores (e.g., 316-C0006E$8 \mathrm{H})$ independent analyses of the different experimental samples (K007 and K010 for that core) have been carried out allowing to estimate internal drill core variations and measurement error. From other cores (e.g., 315-C0001E-11H; K003 and K005) only a sample average has been determined and variations are therefore unknown. See text for further explanation.

and lithics (11-29\%), and sites C0006 and C0007 are rich in minerals (12-17\%) and show an intermediate but variable lithics content (2-26\%). Sediments of the slope apron facies (C0001 and C0004) have only a small amount of ash (1-6\%), slope sediments (C0008) have a large amount (6$8 \%$ ) and the prism toe deposits (C0006 and C0007) have a variable amount (2-9\%). The fossil content is very high for the slope apron facies (34$46 \%$ ), intermediate for the slope sediments (11$24 \%)$ and low for the prism toe deposits $(2-22 \%)$.

\subsection{Particle Size Data}

[21] The grain size distributions of the investigated core samples determined by a laser particle sizer



are shown in Figure 6. The grain sizes of all the samples range from clay to fine sand, but the volume proportion of fine sand is always smaller than $0.03 \%$ (C0006E- $8 \mathrm{H}$; vol. \% in the follwing) and that one of coarse silt is below $0.4 \%$ (C0007C$7 \mathrm{X})$. Hence, in the grain size distribution diagram only the three classes from clay to medium silt are recognizable (Figure 6). Overall, the grain size distribution of the recovered sample material is very homogeneous; similar results are presented by Kopf et al. [2011]. The clay content ranges from 65 to $80 \%$ apart from two exceptions which contain 59 and 86\% (C0006E-20X and C0006E$8 \mathrm{H}$ section 1), respectively. The content of fine silt amounts to $16-29 \%$ again apart from the two exceptions with 34 and $11 \%$ (C0006E-20X and C0006E-8H section 1), respectively. Variability of the medium silt content is smaller ranging from 3 to $7 \%$ with cores $\mathrm{C} 0006 \mathrm{E}-20 \mathrm{X}$ and $\mathrm{C} 0006 \mathrm{E}-8 \mathrm{H}$ section 1 representing again the highest and lowest values, respectively.

[22] The cores from the slope apron facies (C0001E-11H and C0004C-8H) show an almost identical grain size distribution (Figure 6). Variations at one core site (C0008) can be small, but they can also be relatively large (C0006) at the prism toe. Even within one core segment $(\mathrm{C} 0006 \mathrm{E}-8 \mathrm{H})$, the variabilty is almost as great as over the entire sample set, but yet still in agreement to the overall homogeneous grain size distribution.

\section{Geotechnical Experiments}

[23] Results of (1) single step compression experiments at constant confining pressure and displacement rate ("compression tests") (Figure 7), (2) pressure stepping compression experiments at



Figure 7. Compression test results (single step axial compression experiments) at constant displacement rates (indicated in a) and constant confining pressure of $1000 \mathrm{kPa}$. (a) Stress/strain records; sample numbers and displacement rates are indicated. (b) Related pore pressure/strain records; sample numbers are indicated. 


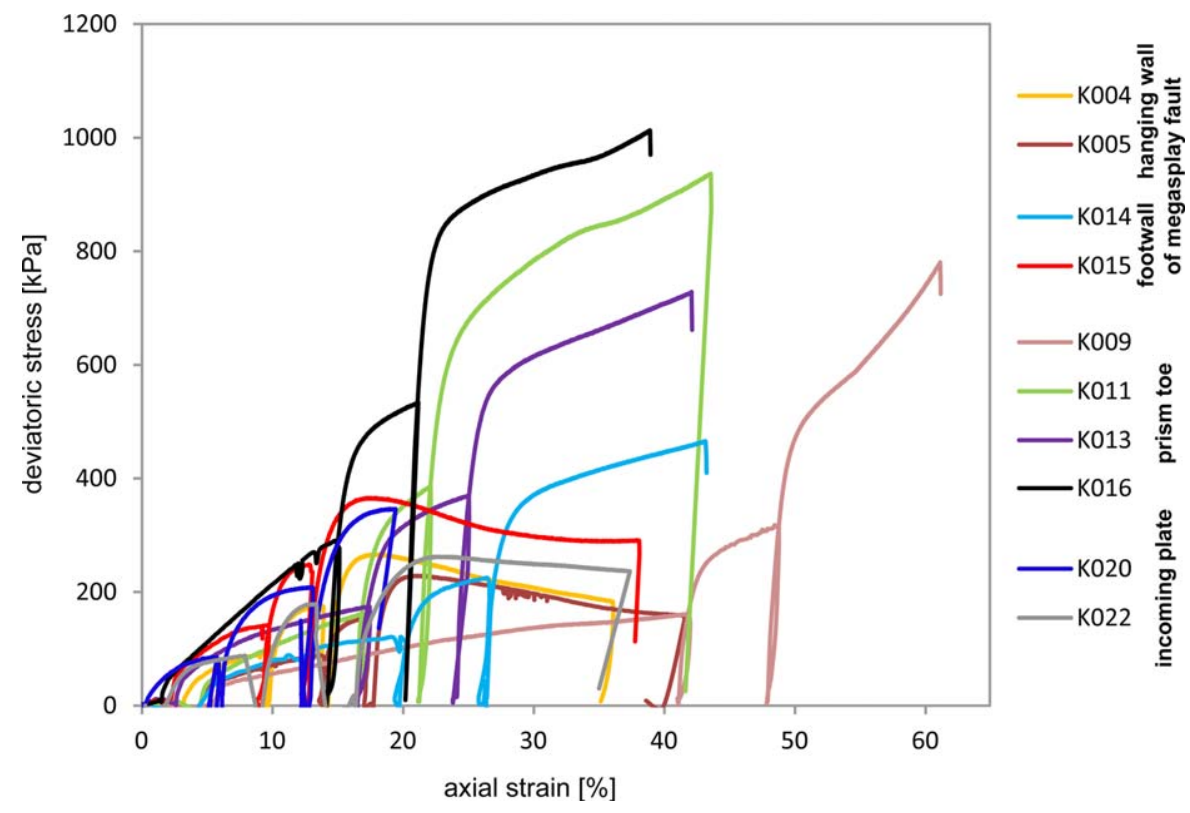

Figure 8. Results of pressure stepping experiments at confining pressures of $400, \sim 640$, and $\sim 1000 \mathrm{kPa}$ and constant displacement rate of $0.01 \mathrm{~mm} / \mathrm{min}$ (for $\mathrm{K} 020$ and $\mathrm{K} 022$ ) or $0.1 \mathrm{~mm} / \mathrm{min}$ (for all other experiments). Stress/strain records, experimental sample numbers and original tectonic settings of the samples are indicated. Related pore pressure/strain records are given in supporting information. See text for further explanation.

constant displacement rate and increasing confining pressures ("pressure stepping tests") (Figure 8), and (3) displacement rate stepping compression experiments at constant confining pressure and increasing displacement rate ("rate stepping tests") (Figure 9) will be described in the following. Attained bulk axial compressive strains in the experiments range from $\sim 12$ to $\sim 48 \%$, whereas most experiments reached $>35 \%$. There is one exception, experiment K009, which was deformed until 64\% axial strain in three steps (Figure 8) in order to check the stability of the assembly. Because it was a structurally strong sample with continuously increasing deviatoric stress with increasing strain, it was also a test if a peak stress exists not far outside the axial strain range usually applied. This was not the case, but the sample got a strongly bulged shape accompanied by inhomogeneous deformation above $45 \%$ strain. That is why steps 2 and 3 of the pressure stepping experiment which achieved $49 \%$ and $64 \%$ bulk strain, respectively, cannot be taken to retrieve the absolute values of the mechanical data.

[24] Bulk strain is composed of the initial compaction strain from pressurization, and either the single deformation step of the compression tests or three or more deformation steps of the pressure or rate stepping tests. Negative strains during piston retraction and stress release between the different steps of the stepping experiments are not accounted for, but can be identified on the stressstrain records (Figures 8 and 9). Deviatoric stresses at peak conditions in the experiments covered a wide range, which is $\sim 250-1000 \mathrm{kPa}$ for $1000 \mathrm{kPa}$ confining pressure and a displacement rate of $0.1 \mathrm{~mm} / \mathrm{min}$. Of course, at lower confining

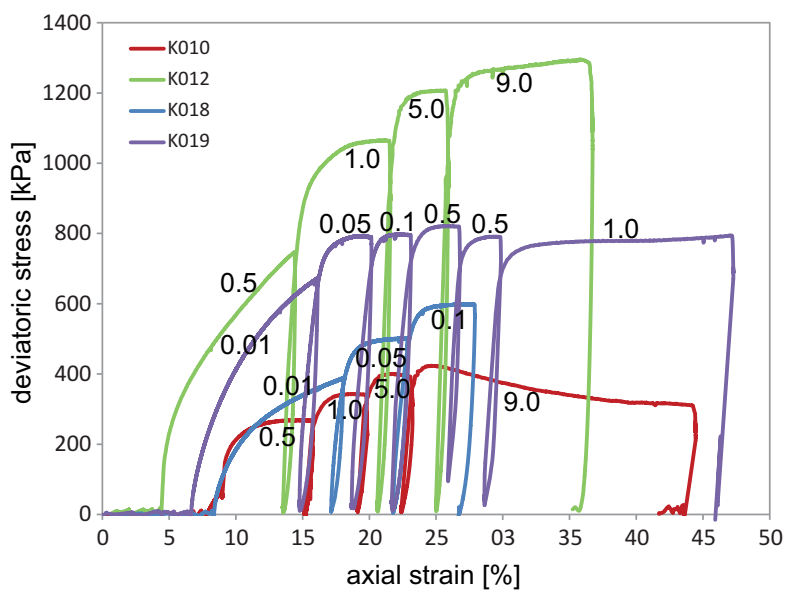

Figure 9. Results of rate stepping experiments at constant confining pressure of $1000 \mathrm{kPa}$ and variable displacement rate. Stress/strain records, displacement rate steps (in $\mathrm{mm} /$ min) and experimental sample numbers are indicated. Related pore pressure/strain records are given in supporting information. See text for further explanation. 
pressure and usually also at slower displacement rate the deviatoric stress was lower than that, and at faster displacement rate it could be even higher.

\subsection{Compression Tests}

[25] The cylindrical samples were deformed at a confining pressure of $\sim 1000 \mathrm{kPa}$ and constant displacement rates of $0.1 \mathrm{~mm} / \mathrm{min}$ or $0.01 \mathrm{~mm} / \mathrm{min}$ (Figure 7; for all experiments see Table in supporting information). Elastic sample deformation is quite similar in the experiments, but after that stress-strain records develop quite differently. Sample K003 reaches a low deviatoric peak stress of $220 \mathrm{kPa}$ after only $8 \%$ strain, while others have much higher stress values (e.g., $680 \mathrm{kPa}, \mathrm{K} 006$ ) or do not show a peak stress, but a continuous stress increase until finite strain (K007; Figure 7a). Sample K003 weakens significantly after peak stress with a stress reduction of $\sim 50 \mathrm{kPa}$ until residual strength of $170 \mathrm{kPa}$ (Figure 7a). These characteristics can also be observed in single steps of the pressure and rate stepping tests presented below. Related pore pressure-strain rate records show all a strong increase parallel to the initial linear deviatoric stress increase. At pore pressures of around $600-700 \mathrm{kPa}$ the curves start to bend. Sample K007 with a continuous and strong deviatoric stress increase until finite strain displays an almost constant or a slightly decreasing pore pressure (Figure 7b). For sample K003, which is characterized by weakening after peak stress, the pore pressure further increases at a more smooth slope. The two other samples (K002 and K006) show slightly increasing pore pressure records until the end of the experiments (Figure 7b), but the finite strain of $\mathrm{K} 002$ is only about $12 \%$.

\subsection{Pressure and Rate Stepping Tests}

[26] Pressure stepping tests were carried out at constant displacement rate of $0.1 \mathrm{~mm} / \mathrm{min}$ and three different confining pressure values of $\sim 400$ $\mathrm{kPa}, 640 \mathrm{kPa}$, and $1000 \mathrm{kPa}$. Additional experiments with reference material from the incoming Phlippine sea plate were conducted at a constant displacement rate of $0.01 \mathrm{~mm} / \mathrm{min}$ and the same pressure steps (K020, K022). From step to step with increasing confining pressure higher deviatoric stresses were achieved. Corresponding to the compression tests they show two groups of contrasting rheological behavior: (1) Samples which fail and weaken afterward (K004, K005, K015, K022; Figure 8), and (2) samples which do not fail, but show a continuous deviatoric stress increase until finite strain (K009, K011, K013,
K014, K016; Figure 8). In K016 a deviatoric stress of more than $1020 \mathrm{kPa}$ could be attained at $1000 \mathrm{kPa}$ confining pressure. The weakening samples (group 1) showed the tendency to approach a residual strength level which is $\sim 290 \mathrm{kPa}$ for $\mathrm{K} 015$ and $\sim 160 \mathrm{kPa}$ for K005. Also the pore pressure development corresponds with a few exceptions to what was observed for the two sample groups in the compression tests, i.e., high pore pressure values and a continuous increase in pore pressure for group 1 and lower pore pressure values and decreasing or almost constant pore pressure toward finite strain for group 2 (see supporting information).

[27] Rate stepping tests were carried out at constant confining pressure of $1000 \mathrm{kPa}$ and from step to step increasing displacement rates from 0.01 $\mathrm{mm} / \mathrm{min}$ to $9 \mathrm{~mm} / \mathrm{min}$. With increasing displacement rate, there is usually an increasing peak deviatoric stress (e.g., K012, K018; Figure 9). However, there is one exception; K019 showed almost no strength increase or even a decrease from step to step, even though after each step the compressive piston was retracted and the differential stress was brought to a small value close to zero prior to advancing the compressive piston at an increased rate. The two groups of contrasting rheological behavior occur also in the rate stepping tests. Group 1 with peak stress, weakening, and residual strength is represented by K010 (Figure 9). The maximum deviatoric stress of this sample at a displacement rate of $9 \mathrm{~mm} / \mathrm{min}$ was quite low $(\sim 420 \mathrm{kPa})$. Experiments $\mathrm{K} 012$ and $\mathrm{K} 018$ with continuously, yet only slightly increasing deviatoric stress toward finite strain belong to group 2. K012 shows a maximum deviatoric stress of $\sim 1300 \mathrm{kPa}$ (Figure 9). The pore pressure development in relation to deviatoric stress very much corresponds to the records of the compression and the pressure stepping tests (see supporting information). However, due to the fast rates of $>0.1$ $\mathrm{mm} / \mathrm{min}$ reaching even $9 \mathrm{~mm} / \mathrm{min}$ an equilibrium pore pressure during each deformation step cannot be assumed and hence the records of the rate stepping tests partially indicate less well equilibrated pore pressure conditions.

\subsection{Effective Shear Parameters}

[28] The effective shear parameters cohesion $\left(C^{\prime}\right)$ and angle of internal friction $\left(\phi^{\prime}\right.$; parameters with prime always indicate effective stress conditions) are determined using the results of the pressure stepping tests. For experiments K004, K005, $\mathrm{K} 015, \mathrm{~K} 020$, and $\mathrm{K} 022 \sigma 1-\sigma 3$ at max. $\sigma 1^{\prime} / \sigma 3^{\prime}$ 


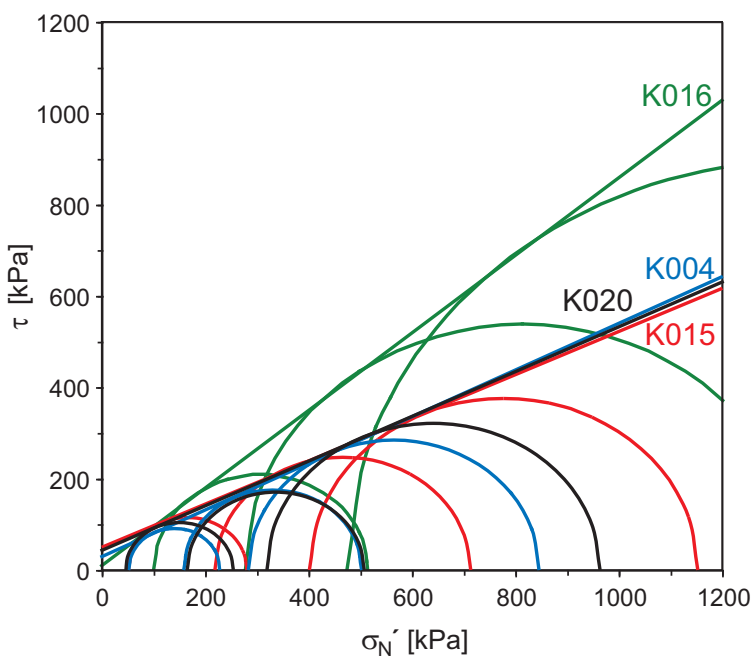

Figure 10. Mohr-Coloumb diagrams from the experiments K004, K015, K016, and K020 with $\tau$ (shear stress) versus $\sigma_{N}$ ' (effective normal stress). Further plots are presented in supporting information.

could be determined from the three pressure steps, and the Mohr-Coulomb condition could be plotted (Figure 10, Table 2; see supporting information for further plots). For the other four pressure stepping experiments a peak strength could not be reached, but the stress-strain records display continuously increasing trends. The German standard DIN 18137 allots $20 \%$ axial strain if stress-strain records increase continuously until finite strain without indication of a stress maximum. However, our experiments have significantly smaller strain steps, because above 35 to $40 \%$ bulk strain the sample cylinders transform into bulged shapes making any further deformation more and more inhomogeneous. Hence, in order to get three reliable pressure steps, the first two were kept within $\sim 10 \%$ axial strain each. Therefore, we define the criterion $\sigma 1-\sigma 3$ at max. $\sigma 1^{\prime} / \sigma 3^{\prime}$ up to $10 \%$ axial strain from which the Mohr-Coulomb condition was plotted for the experiments K009, K011, $\mathrm{K} 013$, K014, and K016. Because several of the individual pressure steps did not even reach $10 \%$ axial strain (especially step 2 of the records), the stress-strain records were extrapolated for those. Strictly speaking, it is not correct to connect the three different pressure steps from those pressure stepping tests which pass the transition from overconsolidated to normally consolidated conditions according to their original overburden (cf. stress paths diagrams in the next paragraph). Nevertheless, the three individual Mohr circles of each pressure step fit very well to the tangential construction of these samples (Figure 10; supporting information). Therefore, we are confident that this connection can be made for the samples and that the error introduced by different consolidation states of the different pressure steps is small.

[29] The resulting $C^{\prime}$ - and $\phi^{\prime}$-values from the Mohr-Coulomb plots are summarized in Table 2. Experiments K004, K005, K014, K015, K020, and K022 show cohesion values of $25-50 \mathrm{kPa}$ and angles of internal friction of 21.5-28.7 in accordance to clay or silty clay [e.g., Carter and Bentley, 1991]. K013 agrees in the cohesion $(29 \mathrm{kPa})$, but has a slightly too high internal friction angle of $32^{\circ}$. Internal friction angles of experiments K011 and K016 are much too high for the sample material $\left(>35^{\circ}\right)$ [cf. Carter and Bentley, 1991] and the cohesion of these two samples is low (12 and 4 $\mathrm{kPa}$, respectively). Weak samples display astonishingly consistent Mohr diagrams whether they come from the megasplay area (K004, K015) or the incoming plate (K020), while strong samples, mostly from the prism toe area (e.g., K016), are considerably different (Figure 10; supporting information).

\subsection{State of Consolidation}

[30] The detected stress paths of the experiments is used to determine the state of sample consolidation, i.e., if the sample is normally consolidated or overconsolidated at the given deformation conditions [e.g., Lambe and Whitman, 1979; Head, 1998]. The sample material suffered different compaction

Table 2. Shear Parameters From the Pressure Stepping Experiments. ${ }^{a}$

\begin{tabular}{|c|c|c|c|c|c|c|c|c|c|}
\hline Experiment & K004 & K005 & K011 & K013 & K014 & K015 & K016 & K020 & K022 \\
\hline Core number & $\mathrm{C} 0004 \mathrm{C}$ & $\mathrm{C} 0001 \mathrm{E}$ & $\mathrm{C} 0007 \mathrm{C}$ & $\mathrm{C} 0006 \mathrm{E}$ & $\mathrm{C} 0008 \mathrm{~A}$ & $\mathrm{C} 0008 \mathrm{C}$ & $\mathrm{C} 0007 \mathrm{C}$ & C0011D & $\mathrm{C} 0012 \mathrm{C}$ \\
\hline Section & $-8 \mathrm{H}-2$ & $-11 \mathrm{H}-1$ & $-7 X-1$ & $-20 X-2$ & $-9 \mathrm{H}-3$ & $-7 \mathrm{H}-8$ & $-7 X-1$ & $-2 \mathrm{H}-2$ & $-4 \mathrm{H}-5$ \\
\hline Depth (mbsf) & 65.26 & 91.00 & 62.89 & 127.98 & 76.06 & 60.96 & 62.89 & 33.10 & 28.90 \\
\hline Cohesion $(\mathrm{kPa})$ & 25.7 & 24.9 & 12.1 & 29.3 & 34.1 & 49.7 & 4.2 & 41.0 & 35.4 \\
\hline Angle of friction & $27.1^{\circ}$ & $24.6^{\circ}$ & $35.8^{\circ}$ & $32.0^{\circ}$ & $28.7^{\circ}$ & $25.3^{\circ}$ & $40.4^{\circ}$ & $26.3^{\circ}$ & $21.5^{\circ}$ \\
\hline
\end{tabular}

${ }^{\mathrm{a}}$ For the experiments K004, K005, K015, K020, and K022 $\sigma 1-\sigma 3$ at maximum $\sigma 1^{\prime} / \sigma 3^{\prime}$, for the other experiments $\sigma 1-\sigma 3$ at maximum $\sigma 1^{\prime} / \sigma 3^{\prime}$ within $10 \%$ axial strain were used. Related Mohr-Coulomb diagrams are shown in Figure 10 and supporting information. See text for further discussion. 

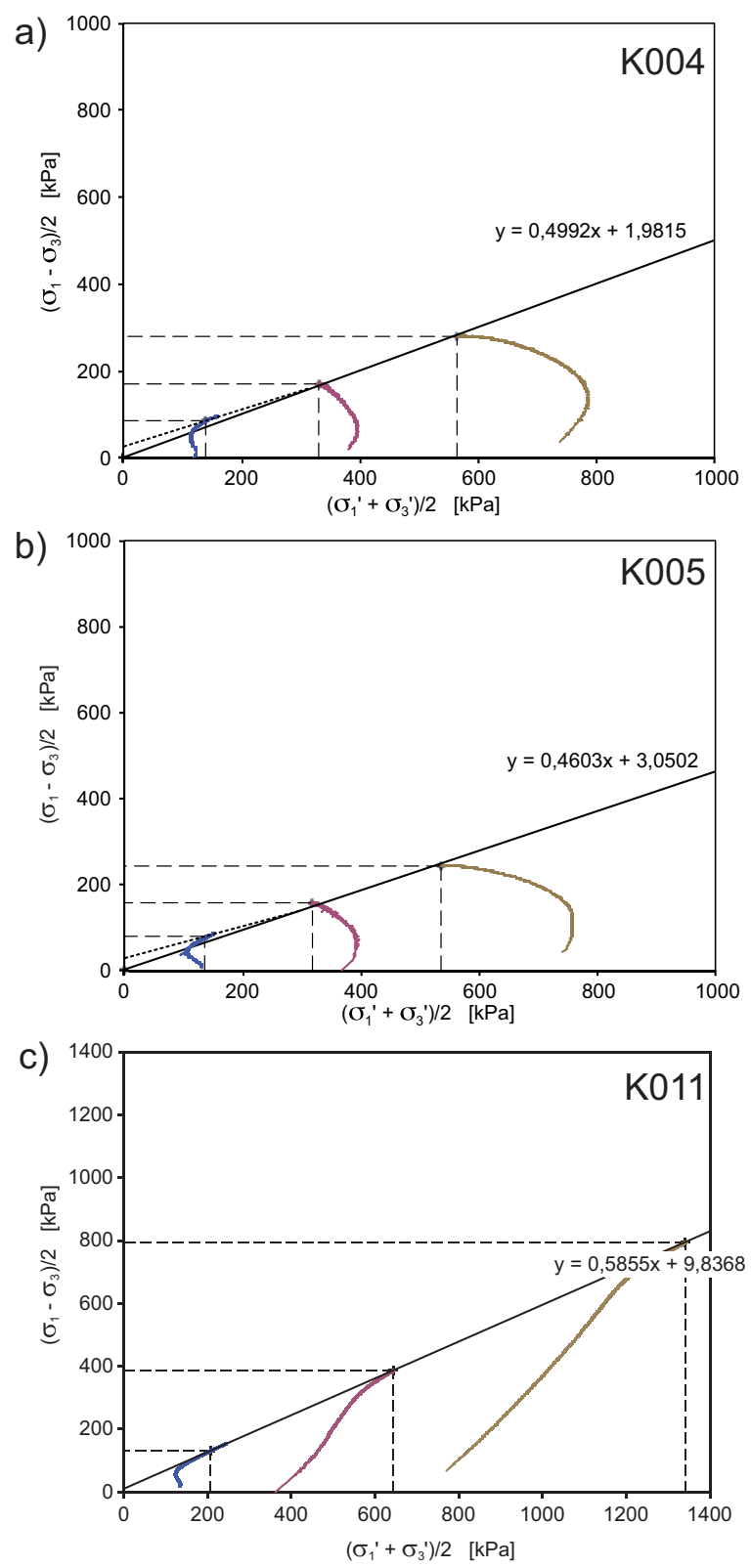

Figure 11. Stress path diagrams with $k_{f}$-line construction of pressure stepping tests (solid lines and possibly stippled lines) with examples of (a) normal consolidation (K004; 65 mbsf), (b) normal consolidation, but sample came from a depth and hence confining pressure greater than the one of the second and third pressure step with a stress path indicating new experimental consolidation (K005; $91 \mathrm{mbsf}$ ), and (c) overconsolidation (K011; $63 \mathrm{mbsf}$ ). Equations of $k_{f}$-lines (solid lines) and the endpoints of different stress paths (depicted by dashed lines) are indicated.

when solely taking the original depths of the cores into account (Table 1) and neglecting any higher overburden previously removed by tectonic or erosive processes or any horizontal compression due to thrusting. Because of the high porosity and pore water content of the samples (Table 1) we assume hydrostatic pressure as minimum pressure estimate. For most of the samples an effective preload of $\sim 300-800 \mathrm{kPa}$ can be derived in that case. Only the cores C0001E-11H (91 m) and C0006E-20X $(128 \mathrm{~m})$ came from significantly greater depth implying preloads of $>900 \mathrm{kPa}$ and $>1300 \mathrm{kPa}$, respectively. Experiments in which the transition from overconsolidated to normally consolidated conditions was passed, i.e., the consolidation level caused by the original effective confining pressure, were plotted with differing $k_{f}$-lines (failure envelopes) according to their consolidation state.

[31] The data (Figure 11; see supporting information for further plots) show that five experiments indicate normal consolidation in agreement with their known overburden (K004, K013, K015, $\mathrm{K} 020$, K022). K005 is also characteristic of normal consolidation, but it displays conditions of new experimental consolidation already for the second pressure step at $640 \mathrm{kPa}$, while the core sample was recovered from $91 \mathrm{~m}$ depth and hence from greater overburden pressure (Figure 11b). In contrast, K011 and K016 ( 63 m depth, both from the same core) imply overconsolidation, because all of their stress paths are indicative of overconsolidated conditions. The stress path of sample K014 shows a reverse curvature and can therefore be termed "quasi-overconsolidated" [Head, 1998]. This record corresponds to what has been found for partially saturated compacted clay.

\section{Discussion}

\subsection{Mechanical Data}

[32] Despite the consistent low depth range and the lithological similarity of the sample cores, the samples studied can be separated into two distinct "rheological groups," as pointed out before. The first group shows deviatoric peak stress after only a few percents of compressional strain $(<10 \%)$ and a continuous stress decrease after peak conditions (Figures 7a, 8, and 9). Simultaneous to this decrease there is a pore pressure increase indicating contractant behavior characteristic of structurally weak material (Figure 7b; supporting information) [e.g., Sultan et al., 2004]. The second sample group does not weaken at all, but displays strengthening characteristics until finite strain (Figures 7a, 8, and 9). These samples are structurally strong [e.g., Sultan et al., 2004], and they are characterized by a decreasing pore pressure with 
increasing compressional strain indicating dilatant behavior after a maximum pore pressure at $<10 \%$ strain (Figure $7 \mathrm{~b}$; supporting information). A few samples with somewhat intermediate behavior reach high deviatoric peak stresses after significantly higher strain $(>10 \%)$ than the structurally weak samples. They weaken only moderately to a relatively high residual strength level or they show a steady state like behavior at constant deviatioric stress (e.g., K006; Figure 7a; K018, Figure 9). Their pore pressure/strain-relationships more or less correspond to what is commonly expected for structurally weak material with some slight variations (Figure $7 \mathrm{~b}$; supporting information).

[33] The pore pressure development during the individual CU tests shows a largely consistent pattern for all the compression and pressure stepping experiments. Structurally weak samples display an increasing pore pressure (contractant behavior) which continues after peak deviatoric stress at or above the confining pressure level of the original sample depth; at low confining pressure $(400 \mathrm{kPa})$ the pore pressure decreases in these samples. The latter suggests that the weakening of the samples at confining pressure lower than that one given by the original overburden is not related to a collapsing pore space. Structurally strong samples display a slightly decreasing pore pressure (dilatant behavior) at or below the confining pressure level of the original sample depth; at higher confining pressures the pore pressure increases in most of these samples. However, pore pressure values are significantly lower than for structurally weak samples.

[34] The rate stepping experiments indicate structurally weak and strong behavior from 0.01 to 9.0 $\mathrm{mm} / \mathrm{min}$, i.e., over almost 3 orders of magnitude (Figure 9). Due to the fast rates in the majority of these experiments pore pressure equilibration could not keep up with the changing stress conditions (see supporting information) as permeabilities are relatively low [e.g., Dugan and Daigle, 2011; Guo et al., 2011; Saffer et al., 2011]. That is why the rate stepping tests with fast displacement rates are not appropriate to derive pore pressure state and development. Nevertheless, the pore pressure disequilibrium could also be relevant in nature, i.e., within the accretionary prism, when deformation is comparably fast. In two of the experiments the stepwise rate increase is always accompanied by an increase in the deviatoric stress level (Figure 9). The structurally weak sample K010 shows considerable weakening after failure of $>100 \mathrm{kPa}$ at the fastest displacement rate of $9.0 \mathrm{~mm} / \mathrm{min}$. The finite deviatoric stress is below the stress level of the previous steps at $5.0 \mathrm{~mm} / \mathrm{min}$ and $1.0 \mathrm{~mm} / \mathrm{min}$, thus showing lower strength at higher displacement rate (Figure 9). Sample K019 shows increasing deviatoric stress with displacement rate increase until 0.5 $\mathrm{mm} / \mathrm{min}$ and decreasing stress with further increasing displacement rate up to $1.0 \mathrm{~mm} / \mathrm{min}$. The sample is relatively strong and does not show the characteristics of a structurally weak sample (Figure 9). Nevertheless, there is almost no deviatoric stress increase above $0.05 \mathrm{~mm} / \mathrm{min}$ or even a decrease above $0.5 \mathrm{~mm} / \mathrm{min}$. This could be interpreted as a kind of strain rate ("velocity") weakening behavior in the displacement rate stepping tests. It is different from what has been observed for the other rate stepping experiments and for single step compression experiments at different displacement rates, for which a faster rate comes along with a higher strength when comparing experiments of otherwise the same conditions and sample material, e.g., K002 and K006 of core sample C0008A-9H (Figure 7). However, further tests are required to constrain this behavior and to check if it might be connected to the structural behavior of the samples.

\subsection{Experimental Errors}

[35] The distinct rheological behavior of the two groups of samples does not depend on the deformation homogeneity, as it is already effective after $\sim 10 \%$ axial strain and remains similar until $\sim 45 \%$ and even much further $(64 \%$ strain of sample K009). This is despite significant buckling of the samples above $45 \%$ strain. Due to the scarce availability of sample material and short drill core segments we had to carry out experiments with cylindrical samples of a length to diameter ratio of $\sim 1: 1$, i.e., deviating from the ideal ratio of $2: 1$. The smaller ratio results in a smaller sample domain of homogeneous deformation. It is also disadvantageous that the end face friction could not be reduced by a lubricant because of otherwise insufficient coupling of the compression and shear wave transducers used in the experiments (K. Schumann, M. Stipp, J. H. Behrmann, D. Klaeschen, and D. Schulte-Kortnack, P- and s-wave velocity measurements of water-rich sediments form Nankai Trough, Japan, submitted to Journal of Geophysical Research, 2013). Nevertheless, there was no effect on the mechanical behavior in comparison to a few experiments on samples with the ideal length to diameter ratio (Figure 8; see table of experiments in supporting information). Both, inhomogeneous deformation and small length to diameter ratio may cause a larger error in the mechanical data, especially in the absolute stress values, which are, however, not critical for our interpretations. 
[36] Stepping experiments inherently include errors related to peak stress and the failure criterion of the sample [e.g., Head, 1998]. It is difficult to exactly terminate the experimental step at peak stress, and in order to avoid severe (micro)structural damage of the samples due to failure, pressure or displacement rate steps were tentatively stopped too early. This was confirmed by highresolution plots of the stress-strain records around finite strain indicating that all of the experimental steps prior to the final step did not decrease in deviatoric stress and hence did not pass the peak stress (failure point). That means, however, that some of the steps of the stepping tests which turned out to be structurally weak were stopped at still increasing deviatoric stress conditions, causing an underestimation of the maximum stress or Mohr-Coulomb failure condition. This directly affects the shear parameters resulting in lower cohesion and internal friction angles [e.g., Smoltc$z y k, 1980]$, as well as the stress path diagrams derived from the pressure stepping tests. Errors in stress are also related to the steps of the structurally strong samples in which a peak stress did not occur, and for which an extrapolation to the defined finite strain of $10 \%$ was made. As the Mohr-Coulomb plots (Figure 10 and Table 2) and also most of the stress paths diagrams of the structurally strong samples (Figure 11) were constructed from three data pairs, and fit quite consistently, we are confident that the stress errors of the data set are small and not critical for the interpretation of our experimental results.

\subsection{Pore Fluid Pressure and its Feedback on the Mechanical Behavior}

[37] Saturation and pore pressure (re-)equilibration are primarily time-dependent variables and thus critical for the sample conditions at the beginning and during an experiment. We have verified by a B-check [DIN 18137, 1990, part 2] that our resaturation procedure of the samples at $300 \mathrm{kPa}$ confining pressure and a back pressure of $280 \mathrm{kPa}$ was successful (see also supporting information). The subsequent increase in confining pressure to reach the desired deformation conditions was accompanied by squeezing out pore water in the experiments as monitored by the water level in the pore water-burette. This pore water discharge during pressurization and prior to starting the CU test further assured saturated and also equilibrated pore water conditions for the experiments.

[38] Displacement rates of at least $0.05 \mathrm{~mm} / \mathrm{min}$ are (according to DIN 18137) slow enough to allow homogeneous deformation at equilibrium pore pressure conditions for CU tests on our samples. Although experiments at $0.1 \mathrm{~mm} / \mathrm{min}$ could be slightly too fast to fully equilibrate the pore fluid pressure in some of the pressure stepping experiments, the pore fluid pressure development is largely consistent and corresponds to either structurally weak or structurally strong behavior. Thus, all the structurally weak samples in Figure 8 have lower deviatoric stresses than the structurally strong samples while the pore fluid pressure records (e.g., Figure OD3, supporting information) show the opposite, all structurally weak samples show higher pore fluid pressures than the structurally strong samples. The records of experiments K002 and K006 are inconsistent (Figure 7). While the faster experiment at $0.1 \mathrm{~mm} / \mathrm{min}$ (K006) is stronger it shows lower pore fluid pressure. Whether this inconsistency is due to pore pressure disequilibrium in K006 deformed at a slightly too fast rate, due to the transitional structural behavior of K006 and maybe also K002, or due to inhomogeneities in composition or microfabrics cannot be explained based on the available data. Therefore, we have to concede that K006 is exceptional, also in comparison to the other compression tests (Figure 7), and that its pore fluid pressure record might be biased.

[39] The otherwise consistent stress and pore fluid pressure data of the experiments carried out at rates of 0.01 and $0.1 \mathrm{~mm} / \mathrm{min}$ are in accordance with rather constant intrinsic permeabilities observed by other geotechnical studies on NanTroSEIZE samples at low confining pressures, i.e., down to a depth of 130 mbsf [Dugan and Daigle, 2011; Guo et al., 2011; Saffer et al., 2011]. Toward greater depth, however, the permeability can be pressure dependent [e.g., Guo et al., 2011; Reuschle, 2011; Saffer et al., 2011]. This confining pressure or depth dependence is superposed by a lithological effect; of course, clay-rich sediments are less permeable than clay-poor and sandrich sediments [e.g., Reuschle, 2011; Rowe et al., 2011]. There might also be a reduction in permeability due to the triaxial stress state, especially at high deviatoric or differential stress [Saffer et al., 2011, Kitajima et al., 2012]. We could not find such an effect at the low deviatoric stresses of our experiments.

\subsection{Geological Significance}

[40] The distinct rheological behavior of structurally weak and structurally strong samples has been observed over the range of applied displacement 
rates and confining pressures in our tests. Hence, it should be effective under comparable natural conditions, and probably also toward higher confining pressures, but this needs to be tested by experiments on samples from greater depth. The elucidation of the controlling parameters and the microphysical processes involved in weakening or strengthening requires microstructural investigations which are beyond the scope of this study. On the base of the presented data, we can spot three reasons which appear to be relevant for the contrasting rheological behavior.

[41] First, the compositional differences: While the rheological differences in the sample set cannot be related to grain or particle size differences (Figure 6), there is some evidence for a dependence on the composition. Structurally weak samples tend to have high contents of organic material and rather low contents of lithics, minerals, and submicroscopic material (e.g., K003, K004, K010; Figure 5). In contrast, structurally strong samples are characterized by high contents of lithics and minerals, and low contents of organic material. Surprisingly, ash contents do not show any clear correlation (Figure 5). Structurally weak samples are high in smectite and structurally strong samples are low in smectite and high in quartz+ chlorite (Figure 4). Overall, a correlation of composition and rheological behavior is recognizable but not very strong. This is probably because the compositional differences between the samples are small.

[42] Second, the state of consolidation: As has been pointed out before, samples show a range from overconsolidation to normal consolidation (Figure 11; supporting information). The state of consolidation largely correlates with the origin of the samples and their original porosities (Table 1). The young sediments of the slope apron facies (hanging wall of the megasplay fault) and the slope sediments (footwall of the megasplay fault) are normally consolidated (K004, K015) with a tendency toward underconsolidation (K005). The low degree of consolidation probably results from the high sedimentation rates and the generally low permeabilities of the silty clay sediments [e.g., Screaton et al., 2002; Gamage and Screaton, 2003; Kinoshita et al., 2009]. The off-scraped trench deposits at the accretionary prism toe (hanging wall of the main frontal thrust) are overconsolidated (K011, K016). Overconsolidation of these sediments is a consequence of erosion and slumping of the original overburden due to oversteepening of the prism toe [Kinoshita et al.,
2009; Screaton et al., 2009], but may additionally be caused by lateral loading [e.g., Feeser et al., 1993]. Lateral loading, however, is not fully consistent with the recorded strain in sediments of the prism toe, which generally shows vertical compression and only shifts to horizontal compression about 400 mbsf at Site C0006 [Kitamura et al., 2010]. Vertical compression can also be derived from the horizontal alignment of clay minerals as indicated by shape and crystallographic preferred orientation analysis [Milliken and Reed, 2010; Guo et al., 2011; Saffer et al., 2011; Schumann et al., in preparation, 2013].

[43] The sediments of the slope apron facies have the highest intial porosities and pore water contents, while the trench deposits have the lowest initial porosities (Table 1). The initial compaction strain representing the consolidation after experimental confining pressure increase and pore pressure relaxation cannot be clearly correlated to the preconsolidation of the samples, though (for porosity development during the drained sample pressurization see Schumann et al., submitted manuscript, 2013). There are normally consolidated samples from the slope apron facies that suffer the same amount of intial compaction during experimental pressurization as overconsolidated samples from the trench deposits at the same confining pressure: For example, $8 \%$ compaction at $1000 \mathrm{kPa}$ confining pressure for samples K010 and $\mathrm{K} 007$, or $4 \%$ at $400 \mathrm{kPa}$ for the normally consolidated sample K005 from greater depth, but even $5 \%$ and 6\% for overconsolidated samples K009 and K011, respectively (see supporting information).

[44] Overconsolidated samples (K011, K016) tend to be structurally strong, normally consolidated samples are weak (K004, K005). However, there are several exceptions, especially for the normally consolidated slope sediments from the footwall of the megasplay fault which are weak (K015) and strong (K014). Hence, the state of consolidation is important, but it does not fully explain the distinct rheological behavior of the sample set.

[45] The discrepancies cannot be explained by cementation as well, because cementation should be insignificant in samples from such shallow depth. Whereas most of the drill sites of the NanTroSEIZE section have been reported of being devoid of any cementation only for Site C0001 a weak cementation of relatively shallow samples has been described [Hashimoto et al., 2010; Raimbourg et al., 2011]. From this site, however, our 
a

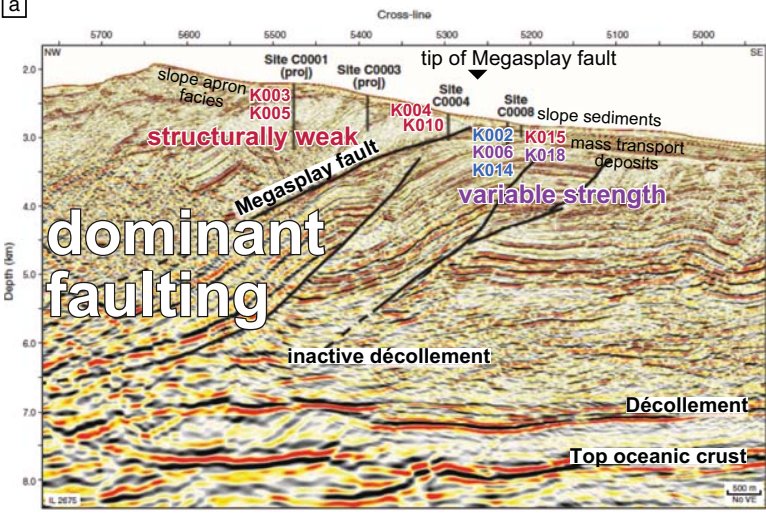

b



Figure 12. Distribution of structurally weak and strong samples in two detailed seismic sections of (a) the tip of the Megasplay fault including drilling sites C0001, C0004, and C0008 [Moore et al., 2009] and (b) the toe of the accretionary prism including drilling sites C0006 and C0007 [Moore et al., 2009]; the positions of these two detailed sections are indicated in Figure 2. Strong samples are located in the prism toe, weak samples in the hanging wall of the Megasplay fault. In the footwall of the Megasplay fault, where the upper sedimentary cover consists of slope sediments, the samples show both, weak and strong behavior. The two experimental samples from Sites C0011 and C0012 which are both structurally weak are not shown as they are located $20 \mathrm{~km}$ away from the plate boundary on the incoming plate. See text for further discussion.

weakest samples (K003, K005) come from suggesting no effect on sample strength.

[46] Third, the deformation conditions: The sediments in the accretionary prism toe above the main frontal thrust, i.e., above the plate boundary (Figure 12), are characterized by intense internal deformation with folding and faulting [e.g., Karig and Lundberg, 1990; Moore et al., 1990; Maltman et al., 1993; Moore et al., 2009]. This deformation is distributed and tends to make the sediments involved stronger by a process akin to strain hardening. In contrast, the sediments from the slope apron facies in the hanging wall of the megasplay fault (Figure 12) [Moore et al., 2009] are less deformed, and only affected by localized faulting [e.g., Milliken and Reed, 2010]. As we avoided fault zone material for the experiments, the sampled sediments should show their original properties, i.e., those that are given prior to fault initiation. The sediments from the footwall of the megasplay fault (Figure 12) represent slope sediments similar to those from the slope apron facies of the hanging wall, as they have a common sedimentary origin. Interestingly, these slope sediments are stronger than the samples from the hanging wall of the megasplay fault. If this greater strength is related to the various fault structures (Figure 12) [Moore et al., 2009] and hence intense faulting and deformation of the footwall block which could have a hardening effect already on the young slope sediments needs to be further tested on samples from greater depth. Alternatively, hardening could also be a consequence of internal working up due to slumping. Samples used for the experiments, however, have been described as slope sediments and not referred to the mass transport deposits which occur below at greater depth. Hence, the contrasting behavior of hanging and footwall sediments is likey related to the differing deformation of the sediments in conjunction with the megasplay activity.

\subsection{Fault Activity}

[47] The megasplay fault is part of a large out-ofsequence thrust system [e.g., Park et al., 2002a; Gulick et al., 2010] and represents a potential coseismic rupture plane [Park et al., 2002a; Moore et al., 2007; Collot et al., 2008; Bangs et al., 2009]. Indeed, recent vitrinite reflectance investigations have shown that both the megasplay fault and the frontal thrust were heated up significantly in the geological past and that this heat can only be attributed to friction by coseismic slip [Sakaguchi et al., 2011]. The eastern portion of the megasplay fault, which crosscuts the NanTroSEIZE drilling section, has been continuously active since its inception approximately 1.95 Ma ago [Kimura et al., 2011]. Hence, there is a distinct fault activity until present and this activity or at least the formation of this megasplay fault may be related to the rheological difference between the uppermost sediments from its hanging wall and footwall. Experimental constraints from the deeper sediments are needed to verify if these rheological properties extend further downward and if they are responsible for the megasplay development. Nevertheless, the investigated, originally undeformed sediments are crucial for the 
formation of surface breaks and tsunami generation in the Nankai accretionary prism.

[48] The tests that we have conducted indicate that both, structurally strong and weak materials are present in different tectonic positions, indicating more distributed ductile deformation and folding at the prism toe and fracturing, faulting and so localized deformation in the megasplay zone. It should be emphasized here that our investigations do not say anything about the deformation along existing fault planes, but they are characteristic of the initial deformation of sediment volumes and the onset of fracturing and fault plane development. Based on our mechanical data, we postulate that the deformation of the structurally weak sediments of the megasplay zone in response to a large seismic event is capable of producing surface breaks and generating tsunamis. Hence, the weak sediments of the slope apron facies can be disrupted by runaway fracturing and faulting in the course of a major earthquake, which may propagate at deeper levels by high-velocity weakening along a preexisting megasplay fault plane, as suggested by Ujiie and Tsutsumi [2010]. In contrast, the structurally strong sediments from the accretionary prism toe are more amenable to slow and distributed deformation (folding), involving large volumes of rock, and hampering the formation of surface breaks. The propagation of tsunami earthquakes is therefore difficult through this zone of structurally strong sediments. The observed difference in rheological behavior could thus be a key for understanding strain concentration and brittle faulting within the rather uniform silty and clayey sedimentary sequence of the Nankai accretionary prism.

\section{Conclusions}

[49] Soft sediments from the Nankai accretionary prism have a variable strength in triaxial compression displayed by peak deviatoric stresses of approximately $200-1000 \mathrm{kPa}$ at $1000 \mathrm{kPa}$ confining pressure and axial displacement rates of 0.01 and $0.1 \mathrm{~mm} / \mathrm{min}$. Strong samples occur at the prism toe, while weak samples predominate at and especially above the megasplay fault, located further upslope. Samples from the incoming plate are also weak, but not as weak as the samples from the hanging wall of the megasplay fault. The strongest sediments display the highest internal friction angles and tend to have lower values of cohesion. Accompanying this strength contrast samples show structurally weak and structurally strong behavior, characterized by strain weakening plus contraction and strain hardening plus dilatation, respectively. The actual reason for this contrasting mechanical behavior of the samples remains unclear. The small differences in composition and grain size seem to be unimportant. However, both the variable consolidation state and the deformation of the sediments explain the differences in behavior to a great extent. If these differences in mechanical behavior of the sediments persist also to greater depth, structurally weak sediments may facilitate strain concentration, cause the formation and stabilization of faults, and provoke mechanical runaway situations. Faulting below the upper and middle slope of the accretionary prism is capable of producing surface breaks, and induces associated tsunamis. Deformation of structurally strong sediments at the prism toe tend to involve large rock volumes and lead to strain dissipation. In this type of setting surface breaks are less likely.

\section{Acknowledgments}

[50] The Integrated Ocean Drilling Program (IODP) provided the sample material for this study and we greatly acknowledge the Shipboard Parties of IODP Expeditions 315, 316, and 333 aboard D/V CHIKYU for their dedicated work. We appreciate the thorough reviews of Yoshitaka Hashimoto and two anonymous reviewers as well as the helpful comments of Thorsten Becker and an anonymous associate editor which significantly improved the manuscript. Supported by Deutsche Forschungsgemeinschaft (DFG) through grant BE1041/28 to J.H.B. and M.S.

\section{References}

Ashi, J., S. Lallemant, H. Masago, and the Expedition 315 Scientists (2008), NanTroSEIZE Stage 1A: NanTroSEIZE megasplay riser pilot, Prelim. Rep. Integrated Ocean Drill. Program, 315, 55 p., doi:10.2204/iodp.pr.315.2008.

Beeler, N. M. (2007), Laboratory-observed faulting in intrinsically and apparently weak materials, in The Seismogenic Zone of Subduction Thrust Faults, edited by T. H. Dixon and J. C. Moore, pp. 370-449, Columbia Univ. Press, New York.

Beeler, N. M., T. E. Tullis, and J. D. Weeks (1994), The roles of time and displacement in the evolution effect in rock friction, Geophys. Res. Lett., 21, 1987-1990.

Berre, T. (1985), Suggested International Code of Soil Engineering Practice for Triaxial Compression Tests, Norwegian Geotechnical Institute (NGI), Norway.

Blanpied, M. L., D. A. Lockner, and J. D. Byerlee (1991), Fault stability inferred from granite sliding experiments at hydrothermal conditions, Geophys. Res. Lett., 18, 609-612.

Brace, W. F., and J. D. Byerlee (1966), Stick-slip as a mechanism for earthquakes, Science, 153, 990-992.

Byerlee, J. (1978), Friction of rocks, Pure Appl. Geophys., $116,615-626$. 
Byrne, D. E., D. M. Davis, and L. R. Sykes (1988), Local and maximum size of thrust earthquakes and the mechanics of the shallow region of subduction zones, Tectonics, 7 , 833-857.

Carter, M., and S. Bentley (1991), Correlations of Soil Properties, 130 pp., Pentech, London.

Chester, F. M. (1994), Effects of temperature on friction: Constitutive equations and experiments with quartz gouge, $J$. Geophys. Res., 99, 7247-7262.

Cloos, M. (1982), Flow melanges: Numerical modeling and geologic constraints on their origin in the Franciscan subduction complex, California, Geol. Soc. Am. Bull., 93, 330-345.

Collot, J. Y., W. Agudelo, A. Ribodetti, and B. Marcailou (2008), Origin of a crustal splay fault and its relation to the seismogenic zone and underplating at the erosional north Ecuador-south Colombia oceanic margin, J. Geophys. Res., 113, B12102, doi:10.1029/2008JB005691.

Dieterich, J. (1972), Time-dependence of rock friction, J. Geophys. Res., 77, 3690-3697.

Dieterich, J. H. (1979), Modeling of rock friction. 1. Experimental results and constitutive equations, J. Geophys. Res., $84,2161-2168$.

DIN 18137 (1990), Testing Procedures and Apparatus: Triaxial Test, Part 2 (German Standard), Berlin.

Dixon, T. H., and J. C. Moore (2007), The Seismogenic Zone of Subduction Thrust Faults, 665 pp., Columbia Univ. Press, New York.

Dugan, B., and H. Daigle (2011), Data report: Permeability, compressibility, stress state, and grain size of shallow sediments from Sites C0004, C0006, C0007, and C0008 of the Nankai accretionary complex, Proc. Integrated Ocean Drill. Program, 314/315/ 316, 11 p., doi:10.2204/iodp.proc.314315316.208.2011.

Feeser, V., K. Moran, and W. Brückmann (1993), Stressregime-controlled yield and strength behavior of sediment from the frontal part of the Nankai accretionary prism, Proc. Ocean Drill. Program Sci. Results, 131, 261-273.

Gamage, K., and E. Screaton (2003). 18. Data report: Permeabilities of Nankai accretionary prism sediments, Proc. Ocean Drill. Program Sci. Results, 190/196, 1-22.

Goldsby, D. L., and T. E. Tullis (2002), Low frictional strength of quartz rocks at subseismic slip rates, Geophys. Res. Lett., 29(17), 1844, doi:10.1029/2002GL015240.

Gulick, S. P. S., N. L. B. Bangs, G. F. Moore, J. Ashi, K. M. Martin, D. S. Sawyer, H. J. Tobin, S. Kuramoto, and A. Taira (2010), Rapid forearc basin uplift and megasplay fault development from 3D seismic images of Nankai margin off Kii Peninsula, Japan, Earth Planet. Sci. Lett., 300, 55-62, doi:10.1016/j.epsl.2010.09.034.

Guo, J., and M. Underwood (2012), Data report: Clay mineral assemblages from the Nankai Trough and Kumano Basin, IODP Expedition 315 and 316, NanTroSEIZE Stage 1, Proc. Integrated Ocean Drill. Program, 314/315/316, doi: 10.2204/iodp.proc.314315316.202.2012.

Guo, J., W. J. Likos, M. B. Underwood, R. M. Skarbek, N. Adamson, and D. Saffer (2011), Data report: Consolidation characteristics of sediments from Sites C0002, C0006, and C0007, IODP Expeditions 315 and 316, NanTroSEIZE Stage 1, Proc. Integrated Ocean Drill. Program, 314/315/ 316, doi:10.2204/iodp.proc.314315316.213.2011.

Hashimoto, Y., H. Tobin, and M. Knuth (2010), Velocityporosity relationship for slope apron and accreted sediments in the Nankai Trough Seismogenic Zone Experiment, Integrated Ocean Drilling Program Expedition 315, Site C0001,
Geochem. Geophys., Geosyst., 11, Q0AD05, doi:10.1029/ 2010GC003217.

Head, K. H. (1998), Effective Stress Tests, Manual of Soil Lab. Test., vol. 3, 2nd ed., 428 pp., John Wiley, Chichester, U. K.

Henry, P., T. Kanamatsu, K. Moe, and the Expedition 333 Scientists (2011), NanTroSEIZE stage 2: Subduction inputs 2 and heat flow, IODP Prel. Rept., 333, 107 p., doi:10.2204/ iodp.proc.333.104.2011.

Hyndman, R. D., and K. Wang (1993), Thermal constraints on the zone of major thrust earthquake failure: The Cascadia subduction zone, J. Geophys. Res., 98, 2039-2060.

Hyndman, R. D., M. Yamano, and D. A. Oleskevich (1997), The seismogenic zone of subduction thrust faults, Isl. Arch., 6(3), 244-260.

Ike, T., G. F. Moore, S. Kuramoto, J.-O. Park, Y. Kaneda, and A. Taira (2008), Variations in sediment thickness and type along the northern Philippine Sea plate at the Nankai Trough, Isl. Arch., 17(3), 342-357, doi:10.1111/j.14401738.2008.00624.x.

Karig, D. E., and N. Lundberg (1990), Deformation bands from the toe of the Nankai accretionary prism, J. Geophys. Res., 95, 9099-9109.

Kimura, G., Y. Kitamura, Y. Hashimoto, A. Yamaguchi, T. Shibata, K. Ujiie, and S. Okamoto (2007), Transition of accretionary wedge structures around the up-dip limit of the seismogenic subduction zone, Earth Planet. Sci. Lett., 225(3-4), 471-484, doi:10.1016/j.eps1.2007.01.005.

Kimura, G., E. J. Screaton, D. Curewitz, and the Expedition 316 Scientists (2008), NanTroSEIZE Stage 1A: NanTroSEIZE shallow megasplay and frontal thrusts, Prelim. Rep. Integrated Ocean Drill. Program, 316, 59 p., doi:10.2204/ iodp.pr.316.2008.

Kimura, G., G. F. Moore, M. Strasser, E. Screaton, D. Curewitz, C. Streiff, and H. Tobin (2011), Spatial and temporal evolution of the megasplay fault in the Nankai Trough, Geochem. Geophys. Geosyst., 12, Q0A008, doi:10.1029/ 2010GC003335.

Kinoshita, M., H. Tobin, J. Ashi, G. Kimura, S. Lallemant, E. J. Screaton, D. Curewitz, H. Masago, K. T. Moe, and the Expedition 314/315/316 Scientists (2009), NanTroSEIZE Stage 1: Investigations of Seismogenesis, Nankai Trough, Japan, Proc. Integrated Ocean Drill. Program, 314/315/316, doi:10.2204/iodp.proc.314315316.2009.

Kitajima, H., F. M. Chester, and G. Biscontin (2012), Mechanical and hydraulic properties of Nankai accretionary prism sediments: Effect of stress path, Geochem. Geophys. Geosyst., 13, Q0AD27, doi:10.1029/2012GC004124.

Kitamura, Y., et al. (2005), Melange and its seismogenic roof decollement: A plate boundary fault rock in the subduction zone-An example from the Shimanto Belt, Japan, Tectonics, 24, TC5012, doi:10.1029/2004TC001635.

Kitamura, Y., T. Kanamatsu, and X. Zhao (2010), Structural evolution in accretionary prism toe revealed by magnetic fabric analysis from IODP NanTroSEIZE Expedition 316, Earth Planet. Sci. Lett., 292, 221-230, doi:210.1016/ j.eps1.2010.1001.1040.

Kopf, A., M. Strasser, N. Monsees, M. B. Underwood, and J. Guo (2011), Data report: Particle size analysis of sediments recovered during IODP Expeditions 315 and 316, Sites C0001-C0008, Nankai Trough forearc, off Japan, Proc. Integrated Ocean Drill. Program, 314/315/316, doi: 10.2204/iodp.proc.314315316.207.2011.

Laberg, J. S., T. O. Vorren, J. Mienert, H. Haflidason, P. Bryn, and R. Lien (2003), Preconditions leading to the Holocene Trænadjupet Slide offshore Norway, in Advances in Natural 
and Technological Hazards Research, edited by J. Locat, and J. Mienert, pp. 247-254, Kluwer, Dordrecht, Netherlands.

Lambe, T. W., and R. V. Whitman (1979), Soil Mechanics, SI ed., John Wiley, New York.

Linker, M. F., and J. H. Dieterich (1992), Effects of variable normal stress on rock friction: Observations and constitutive relations, J. Geophys. Res., 97, 4923-4940.

Logan, J. M., and K. A. Rauenzahn (1987), Frictional dependence of gouge mixtures of quartz and montmorillonite on velocity, composition and fabric, Tectonophysics, 144, 87-108.

Lupini, J. F., A. E. Skinner, and P. R. Vaughan (1981), The drained residual strength of cohesive soils, Geotechnique, 31, 181-213.

Maltman, A. J., T. Byrne, D. E. Karig, S. Lallemant, R. Knipe, and D. Prior (1993), Deformation structures at site 808, Nankai accretionary prism, Japan, in Proc. Ocean Drill. Program Sci. Results, 131, 123-133.

Marone, C., and C. H. Scholz (1988), The depth of seismic faulting and the upper transition fromstable to unstable slip regimes, Geophys. Res. Lett., 15, 621-624.

Milliken, K. L., and R. M. Reed (2010), Multiple causes of diagenetic fabric anisotropy in weakly consolidated mud, Nankai accretionary prism, IODP Expedition 316, J. Struct. Geol., 32, 1887-1898.

Miyazaki, S., and K. Heki (2001), Crustal velocity field of southwest Japan: Subduction and arc-arc collision, J. Geophys. Res., 106, 4305-4326, doi:10.1029/2000JB900312.

Moore, G. F., T. H. Shipley, P. L. Stoffa, D. E. Karig, S. Taira, H. Kuramoto, K. Tokuyama, and K. Suyehiro (1990), Structure of the Nankai Trough accretionary zone from multichannel seismic-reflection data, J. Geophys. Res., 95, 8753-8765.

Moore, G. F., et al. (2001), New insights into deformation and fluid flow processes in the Nankai Trough accretionary prism: Results of Ocean Drilling Program Leg 190, Geochem. Geophys. Geosyst., 2(10), 1058, doi:10.1029/2001GC000166.

Moore, G. F., N. L. Bangs, A. Taira, S. Kuramoto, E. Pangborn, and H. J. Tobin (2007), Three-dimensional splay fault geometry and implications for tsunami generation, Science, 318, 1128-1131, doi:10.1126/science.1147195.

Moore, G. F., J.-O. Park, N. L. Bangs, S. P. Gulick, H. J. Tobin, Y. Nakamura, S. Sato, T. Tsuji, T. Yoro, H. Tanaka, S. Uraki, Y. Kido, Y. Sanada, S. Kuramoto, and A. Taira (2009), Structural and seismic stratigraphic framework of the NanTroSEIZE Stage 1 transect, in M. Kinoshita, H. Tobin, J. Ashi, G. Kimura, S. Lallemant, E. J. Screaton, D. Curewitz, H. Masago, K. T. Moe, and the Expedition 314/315/316 Scientists, Proc. IODP, 314/315/316, Integrated Ocean Drilling Program Management International, Inc., Washington, DC, doi:10.2204/iodp.proc.314315316.102.2009.

Moore, J. C., and D. M. Saffer (2001), Updip limit of the seismogenic zone beneath the accretionary prism of southwest Japan: An effect of diagenetic to low-grade metamorphic processes and increasing effective stress, Geology, 29, 183-186.

Morgan, J. K., E. B. Ramsey, and M. V. S. Ask (2007), Deformation and mechanical strength of sediments at the Nankai subduction zone, in The Seismogenic Zone of Subduction Thrust Faults, edited by T. H. Dixon and J. C. Moore, pp. 210-256, Columbia Univ. Press, New York.

Okino, K., Y. Shimakawa, and S. Nagaoka (1994), Evolution of the Shikoku Basin, J. Geomagn. Geoelectr., 46(6), 463-479.

Oleskevich, D. A., R. D. Hyndman, and K. Wang (1999), The updip and downdip limits to great subduction eathquakes:
Thermal and structural models of Cascadia, south Alaska, SW Japan, and Chile, J. Geophys. Res., 104, 14,965-14,991.

Park, J.-O., T. Tsuru, S. Kodaira, P. R. Cummins, and Y. Kaneda (2002a), Splay fault branching along the Nankai subduction zone, Science, 297, 1157-1160.

Park, J.-O., T. Tsuru, N. Takahashi, T. Hori, S. Kodaira, A. Nakanishi, S. Miura, and Y. Kaneda (2002b), A deep strong reflector in the Nankai accretionary wedge from multichannel seismic data: Implications for underplating and interseismic shear stress release, J. Geophys. Res., 107(B4), 2061, doi: 10.1029/2001JB000262.

Raimbourg, H., Y. Hamano, S. Saito, M. Kinoshita, and A. Kopf (2011), Acoustic and mechanical properties of Nankai accretionary prism core samples, Geochem., Geophys., Geosyst., 12, Q0AD10, doi:10.1029/2010GC003169.

Reuschle, T. (2011), Data report: Permeability measurements under confining pressure, Expeditions 315 and 316, Nankai Trough, Proc. Integrated Ocean Drill. Program, 314/315/ 316, doi: 10.2204/iodp.proc.314315316.205.2011.

Rice, J. R., and A. L. Ruina (1983), Stability of steady frictional slipping, J. Appl. Mech., 50, 343-349.

Rowe, K., E. Screaton, J. Guo, and M. B. Underwood (2011), Data report: Permeabilities of sediments from the Kumano Basin transect off Kii Peninsula, Japan, Proc. Integrated Ocean Drill. Program, 314/315/316, doi:10.2204/ iodp.proc.314315316.211.2011.

Saffer, D., J. Guo, M. B. Underwood, W. Likos, R. M. Skarbek, I. Song, and M. Gildow (2011), Data report: Consolidation, permeability, and fabric of sediments from the Nankai continental slope, IODP Sites C0001, C0008, and C0004, Proc. Integrated Ocean Drill. Program, 314/315/ 316, doi:10.2204/iodp.proc.314315316.218.2011.

Saffer, D. M., and C. Marone (2003), Comparison of smectiteand illite-rich gouge frictional properties: Application to the updip limit of the seismogenic zone along subduction megathrusts, Earth Planet. Sci. Lett., 215, 219-235.

Sakaguchi, A., et al. (2011), Seismic slip propagation to the updip end of plate boundary subduction interface faults: Vitrinite reflectance geothermometry on Integrated Ocean Drilling Program NanTroSEIZE cores, Geology, 39, 395-398, doi: 10.1130/G31642.1.

Scholz, C. H. (1998), Earthquakes and friction laws, Nature, $391,37-42$.

Scholz, C. H. (2002), The Mechanics of Earthquakes and Faulting, 464 pp., Cambridge Univ. Press, Cambridge, U. K. Screaton, E., D. Saffer, P. Henry, S. Hunze, and the Leg 190 Shipboard Science Party (2002), Porosity loss within the underthrust sediments of the Nankai accretionary complex: Implications for overpressures, Geology, 30, 19-22.

Screaton, E., et al. (2009), Interactions between deformation and fluids in the frontal thrust region of the NanTroSEIZE transect offshore the Kii Peninsula, Japan: Results from IODP Expedition 316 Sites C0006 and C0007, Geochem. Geophys. Geosyst., 10, Q0AD01, doi:10.1029/ 2009GC002713.

Seno, T., S. Stein, and A. E. Gripp (1993), A model for the motion of the Philippine Sea plate consistent with NUVEL-1 and geological data, J. Geophys. Res., 98, 17,941-17,948, doi:10.1029/93JB00782.

Smoltczyk, U. (1980), Grundbau Taschenbuch, 3rd ed., part 1, Wilhelm Ernst and Sohn, Berlin.

Sultan, N., P. Cochonat, M. Canals, A. Cattaneo, B. Dennielou, H. Haflidason, J. S. Laberg, D. Long, J. Mienert, F. Trincardi, R. Urgeles, T. O. Vorren, and C. Wilson (2004), Triggering mechanisms of slope instability processes 
and sediment failures on continental margins: A geotechnical approach, Mar. Geol., 213, 291-321.

Terzaghi, K., R. B. Peck, and G. Mesri (1996), Soil Mechanics in Engineering Practice, 3rd ed., 592 p., John Wiley, New York.

Tichelaar, B. W., and L. J. Ruff (1993), Depth of seismic coupling along subduction zones, J. Geophys. Res., 98, 2017-2037.

Tobin, H., and M. Kinoshita (2006), NanTroSEIZE: The IODP Nankai Trough seismogenic zone experiment, Sci. Drill., 2, 23-27, doi:10.2204/iodp.sd.2.06.2006.

Tobin, H., and M. Kinoshita (2007), The IODP Nankai Trough seismogenic zone experiment, in Reports on Deep Earth Sampling and Monitoring, Sci. Drill. Spec. Issue, 1, pp. 3941, doi:10.2204/iodp.sd.s01.30.2007.

Tobin, H., M. Kinoshita, J. Ashi, S. Lallemant, G. Kimura, E. J. Screaton, K. T. Moe, H. Masago, D. Curewitz, and the Expedition 314/315/316 Scientists (2009), NanTroSEIZE Stage 1 expeditions: Introduction and synthesis of key results, in M. Kinoshita, H. Tobin, J. Ashi, G. Kimura, S. Lallemant, E. J. Screaton, D. Curewitz, H. Masago, K. T. Moe, and the Expedition 314/315/316 Scientists, Proc. $I O D P, 314 / 315 / 316$, Integrated Ocean Drilling Program Management International, Inc., Washington, DC, doi: 10.2204/iodp.proc.314315316.101.2009.
Tullis, T. E., and J. D. Weeks (1986), Constitutive behavior and stability of frictional sliding of granite, Pure Appl. Geophys., 124, 383-414.

Ujiie, K., and A. Tsutsumi (2010), High-velocity frictional properties of clay-rich fault gouge in a megasplay fault zone, Nankai subduction zone, Geophys. Res. Lett., 37, L24310, doi:10.1029/2010GL046002.

Underwood, M. B. (2007), Sediment inputs to subduction zones: Why lithostratigraphy and clay mineralogy matter, in The Seismogenic Zone of Subduction Thrust Faults, edited by T. H. Dixon and J. C. Moore, pp. 42-85, Columbia Univ. Press, New York.

Vardoulakis, I. (1979), Bifurcation analysis of the triaxial test on sand samples, Acta Mech., 32, 35-54.

von Huene, R. (1984), Tectonic processes along the front of modern convergent margins-research of the past decade, Ann. Rev. Earth Planet. Sci., 12, 359-382.

Vrolijk, P. (1990), On the mechanical role of smectite in subduction zones, Geology, 18, 703-707.

Wallace, L. M., et al. (2009), Characterizing the seismogenic zone of a major plate boundary subduction thrust: Hikurangi Margin, New Zealand, Geochem. Geophys. Geosyst., 10, Q10006, doi:10.1029/2009GC002610. 